\title{
Improvement and evaluation of simulated global biogenic soil NO emissions in an AC-GCM
}

\author{
J. Steinkamp ${ }^{1, *}$ and M. G. Lawrence ${ }^{1,2}$ \\ ${ }^{1}$ Max-Planck-Institute for Chemistry, Department of Atmospheric Chemistry, Mainz, Germany \\ ${ }^{2}$ University of Mainz, Institute for Physics of the Atmosphere, Mainz, Germany \\ * now at: LOEWE - Biodiversity and Climate Research Centre (BiK-F), Frankfurt/Main, Germany
}

Received: 27 May 2010 - Published in Atmos. Chem. Phys. Discuss.: 30 June

Revised: 27 May 2011 - Accepted: 9 June 2011 - Published: 28 June 2011

\begin{abstract}
Biogenic $\mathrm{NO}$ emissions from soils $\left(\mathrm{SNO}_{\mathrm{x}}\right)$ play important direct and indirect roles in tropospheric chemistry. The most widely applied algorithm to calculate $\mathrm{SNO}_{\mathrm{x}}$ in global models was published 15 years ago by Yienger and Levy (1995), and was based on very few measurements. Since then, numerous new measurements have been published, which we used to build up a compilation of world wide field measurements covering the period from 1978 to 2010. Recently, several satellite-based top-down approaches, which recalculated the different sources of $\mathrm{NO}_{\mathrm{x}}$ (fossil fuel, biomass burning, soil and lightning), have shown an underestimation of $\mathrm{SNO}_{\mathrm{x}}$ by the algorithm of Yienger and Levy (1995). Nevertheless, to our knowledge no general improvements of this algorithm, besides suggested scalings of the total source magnitude, have yet been published. Here we present major improvements to the algorithm, which should help to optimize the representation of $\mathrm{SNO}_{\mathrm{x}}$ in atmosphericchemistry global climate models, without modifying the underlying principals or mathematical equations. The changes include: (1) using a new landcover map, with twice the number of landcover classes, and using annually varying fertilizer application rates; (2) adopting a fraction of $1.0 \%$ for the applied fertilizer lost as NO, based on our compilation of measurements; (3) using the volumetric soil moisture to distinguish between the wet and dry states; and (4) adjusting the emission factors to reproduce the measured emissions in our compilation (based on either their geometric or arithmetic mean values). These steps lead to increased global annual $\mathrm{SNO}_{\mathrm{x}}$, and our total above canopy $\mathrm{SNO}_{\mathrm{x}}$ source of $8.6 \mathrm{Tg} \mathrm{yr}^{-1}$ (using the geometric mean) ends up being close to one of the satellite-based top-down approaches $\left(8.9 \mathrm{Tg} \mathrm{yr}^{-1}\right)$. The above canopy $\mathrm{SNO}_{\mathrm{x}}$ source using the
\end{abstract}

Correspondence to: J. Steinkamp (joerg.steinkamp@senckenberg.de) arithmetic mean is $27.6 \mathrm{Tg} \mathrm{yr}^{-1}$, which is higher than all previous estimates, but compares better with a regional topdown study in eastern China. This suggests that both topdown and bottom-up approaches will be needed in future attempts to provide a better calculation of $\mathrm{SNO}_{\mathrm{x}}$.

\section{Introduction}

Nitrogen oxides $\left(\mathrm{NO}_{\mathrm{x}}=\mathrm{NO}+\mathrm{NO}_{2}\right)$ play an important role in the chemical processes of the atmosphere, especially in the production and destruction of ozone (Chameides et al., 1992). On a global scale, $\mathrm{NO}_{\mathrm{x}}$ emissions are dominated by anthropogenic combustion processes, which contribute $20-24 \mathrm{Tg}(\mathrm{N}) \mathrm{yr}^{-1}$ (Denman et al., 2007). The biogenic NO emission flux from soils (hereafter $\mathrm{SNO}_{\mathrm{x}}$ ) contributes 5.5 to $21 \mathrm{Tg}(\mathrm{N}) \mathrm{yr}^{-1}$ (Yienger and Levy, 1995; Davidson and Kingerlee, 1997) and is in the same range as NO produced by lightning and biomass burning. However, in a previous study we showed that due to the geographical distribution of modeled $\mathrm{SNO}_{\mathrm{x}}$, its influence on the reaction chain from $\mathrm{NO}_{\mathrm{x}}$ through $\mathrm{O}_{3}$ and $\mathrm{OH}$ to the oxidizing efficiency is stronger than for the other surface sources (Steinkamp et al., 2009).

In recent years, measurements of the $\mathrm{NO}_{2}$ column from satellites have been used in "top-down" approaches to optimize emissions from various sources, including $\mathrm{SNO}_{\mathrm{x}}$ (Martin et al., 2003; Bertram et al., 2005; Jaeglé et al., 2005; Müller and Stavrakou, 2005; Martin et al., 2006). Coming from the other direction, "bottom-up" approaches have used various algorithms for estimating $\mathrm{SNO}_{\mathrm{x}}$ based on soil and climatological parameters. The most widely used algorithm to calculate $\mathrm{SNO}_{\mathrm{x}}$ was developed 15 years ago by Yienger and Levy (1995) (hereafter YL95) and has been applied in numerous global atmospheric chemistry models (e.g. Lawrence et al., 1999; Ganzeveld et al., 2002; Horowitz et al., 2003;

Published by Copernicus Publications on behalf of the European Geosciences Union. 
Martin et al., 2003; Hauglustaine et al., 2004; Jaeglé et al., 2005; Müller and Stavrakou, 2005; Jöckel et al., 2006; Delon et al., 2008; van der A et al., 2008). In comparison to most of the top-down studies, $\mathrm{SNO}_{\mathrm{x}}$ seems to be generally underestimated by the algorithm of Yienger and Levy (1995). Since the publication of YL95, many more measurements have been carried out and published than were available at the time of YL95, which could potentially reduce the discrepancy.

Here we present major improvements to the algorithm by YL95 and derive updated emission factors, which could easily be used in other models as well. These new emission factors are calibrated in a bottom-up approach with a global compilation of measurements of $\mathrm{SNO}_{\mathrm{x}}$. We then compare our simulated emissions to the a posteriori top-down emissions of Jaeglé et al. (2005), and discuss them in the context of other top-down studies by Müller and Stavrakou (2005), Wang et al. (2007), Stavrakou et al. (2008), and Zhao and Wang (2009).

\section{Model framework and measurement compilation}

For this study we applied the ECHAM5/MESSy Atmospheric Chemistry (EMAC) model (ECHAM5 version 5.3.01, MESSy version 1.6), which is a numerical chemistry and climate simulation system that includes sub-models describing tropospheric and middle atmospheric processes and their interaction with oceans, land and human influences (Jöckel et al., 2006). It uses the first version of the Modular Earth Submodel System (MESSy1) to link multi-institutional computer codes. The core atmospheric model is the 5th generation European Centre Hamburg general circulation model ECHAM5 (Roeckner et al., 2006). The MESSy submodels switched on here simulated cloud microphysics and stratiform precipitation (CLOUD), deep convection dynamics and precipitation (CONVECT, Tost et al., 2006), online emissions (ONLEM, Kerkweg et al., 2006) and the global solar and terrestrial radiative energy budgets (RAD4ALL).

We performed a simulation covering the period from 1990 to 2000, during which most of the measurements in our compilation were performed. We nudged our simulation by the ECMWF ERA40 data (Uppala et al., 2005), with a spherical truncation of T106 (approx. 1.1 by $1.1^{\circ}$ ) and 31 pressure levels. Although it would be possible to compute the $\mathrm{SNO}_{\mathrm{x}}$ source directly using the ERA40 data, which provides the relevant parameters (soil moisture and temperature) at a higher resolution, we instead apply the EMAC model at a coarser spatial resolution, since the results of our study are intended for use in similarly coarse atmospheric chemistry models (and the calculation of soil moisture differs between ERA40 and EMAC Drusch et al., 2009; Roeckner et al., 2003).

$\mathrm{SNO}_{\mathrm{x}}$ is calculated in the submodel ONLEM according to the algorithm by Yienger and Levy (1995) implemented by Ganzeveld et al. $(2002,2006)$ (hereafter called
YL95EMAC). We then use the soil temperature, soil wetness and precipitation from this simulation as input for offline calculations of $\mathrm{SNO}_{\mathrm{x}}$, with improvements applied in 4 steps (each building on the previous step):

1. Introduction of a new landcover map, using yearly varying fertilizer data for fertilizer induced emissions (FIE) and applying a modified pulsing routine ("LC", Sects. 3.1 and 3.2).

2. Reduction of $\mathrm{NO}$ emission from fertilizer application (“LC + FIE", Sect. 3.4).

3. Use of volumetric soil moisture instead of soil water column ("LC + FIE + VSM", Sect. 3.5).

4. Recalibration of emission factors with measurements ("YL95/SL11", Sect. 3.6.).

\subsection{State of the art model}

The parametrization by YL95 distinguishes between two soil moisture states. YL95 uses the precipitation rates of the previous 14 days, whereas in YL95EMAC the water content in the soil is used to distinguish between dry and wet soil conditions. $\mathrm{SNO}_{\mathrm{x}}$ flux $\left(F_{\text {soil }}\right.$ in $\left.\mathrm{ng} \mathrm{m}^{-2} \mathrm{~s}^{-1}\right)$ is calculated based on a statistically derived dry $\left(A_{\mathrm{d}}\right)$ and wet $\left(A_{\mathrm{w}}\right)$ emission factor (both in $\mathrm{ng} \mathrm{m}^{-2} \mathrm{~s}^{-1}$ ) for 12 different ecosystems and a temperature dependence according to the Eqs. (1a) and (1b) with $T$ in ${ }^{\circ} \mathrm{C}$.

$F_{\text {soil }}\left(T, A_{\mathrm{w}}\right)= \begin{cases}0.28 \cdot T \cdot A_{\mathrm{w}} & 0^{\circ} \mathrm{C}<T \leq 10^{\circ} \mathrm{C} \\ e^{0.103 \cdot T} \cdot A_{\mathrm{w}} & 10^{\circ} \mathrm{C}<T \leq 30^{\circ} \mathrm{C} \\ 21.97 \cdot A_{\mathrm{w}} & T>30^{\circ} \mathrm{C}\end{cases}$

$F_{\text {soil }}\left(T, A_{\mathrm{d}}\right)= \begin{cases}\frac{T}{30} \cdot A_{\mathrm{d}} & 0^{\circ} \mathrm{C}<T \leq 30^{\circ} \mathrm{C} \\ A_{\mathrm{d}} & T>30^{\circ} \mathrm{C}\end{cases}$

For rainforests, constant emissions were assumed for the dry and wet seasons. Agricultural areas are calculated like wet grassland, plus a fraction of the applied fertilizer (see below). In the YL95EMAC simulation the twelve ecosystems (Table 1, 4th column) defined by YL95 are based on the 72 ecosystems of Olson (1992). The emission reduction in "rice-producing areas" of eastern Asia and eastern India as described in YL95 are not implemented in the YL95EMAC algorithm.

The calculated flux is then multiplied by a pulsing factor, which emulates the physical sudden pulse of NO that is known to occur when precipitation falls after a dry period. If the accumulated precipitation was less then $10 \mathrm{~mm}$ in a gridcell during the last 14 days, and the precipitation then exceeds $1 \mathrm{~mm}$ ("sprinkle"), $5 \mathrm{~mm}$ ("shower") or $15 \mathrm{~mm}$ ("heavy rain") during one day, an increase of the emission rate by the

\footnotetext{
${ }^{1}$ SL11 refers to this study
} 
Table 1. World surface areas of the YL95EMAC ecosystems and new YL95/SL11 landcover classes in the EMAC model. For YL95EMAC the first number is as adopted from Olson (1992) and the number in brackets gives the area reduced by $(1-$ cultivation index $)$ for non-agricultural areas and the cultivated area for agriculture with the cultivation index after Bouwman et al. (2002).

\begin{tabular}{|c|c|c|c|c|c|}
\hline \multirow[b]{2}{*}{ ID } & \multirow{2}{*}{$\begin{array}{l}\text { MODIS } \\
\text { landcover }\end{array}$} & \multirow{2}{*}{$\begin{array}{c}\text { Köppen } \\
\text { main climate }\end{array}$} & \multirow{2}{*}{$\begin{array}{l}\text { YL95EMAC } \\
\text { ecosystem }\end{array}$} & \multicolumn{2}{|c|}{ Area $\left[10^{6} \mathrm{~km}^{2}\right]$} \\
\hline & & & & YL95/SL11 & YL95EMAC \\
\hline 0 & Water & - & Water & 364.18 & $367.15(364.3)$ \\
\hline 1 & Permanent wetland & - & & 0.30 & \\
\hline 2 & Snow and ice & - & Ice & 16.12 & $15.44(15.44)$ \\
\hline 3 & Barren & $\mathrm{D}, \mathrm{E}$ & & 2.28 & \\
\hline 4 & Unclassified & - & & 0.07 & \\
\hline 5 & Barren & $\mathrm{A}, \mathrm{B}, \mathrm{C}$ & Desert & 17.68 & $17.23(16.71)$ \\
\hline 6 & Closed shrubland & - & Shrubland & 0.75 & $0(0)$ \\
\hline 7 & Open shrubland & $\mathrm{A}, \mathrm{B}, \mathrm{C}$ & & 14.85 & \\
\hline 8 & Open shrubland & $\mathrm{D}, \mathrm{E}$ & Tundra & 11.85 & $11.61(11.36)$ \\
\hline 9 & Grassland & $\mathrm{D}, \mathrm{E}$ & & 0.46 & \\
\hline 10 & Savannah & $\mathrm{D}, \mathrm{E}$ & & 4.66 & \\
\hline 11 & Savannah & $\mathrm{A}, \mathrm{B}, \mathrm{C}$ & Grassland & 9.76 & $33.10(27.12)$ \\
\hline 12 & Grassland & $\mathrm{A}, \mathrm{B}, \mathrm{C}$ & & 8.80 & \\
\hline 13 & Woody savannah & - & Woodland & 10.94 & $14.16(7.98)$ \\
\hline 14 & Mixed forest & - & Dec. forest & 6.87 & $5.07(3.41)$ \\
\hline 15 & Evergr. broadl. forest & $\mathrm{C}, \mathrm{D}, \mathrm{E}$ & & 1.97 & \\
\hline 16 & Dec. broadl. forest & $\mathrm{C}, \mathrm{D}, \mathrm{E}$ & & 1.66 & \\
\hline 17 & Dec. needlel. forest & - & & 0.93 & \\
\hline 18 & Evergr. needlel. forest & - & Conif. forest & 5.78 & $15.81(14.45)$ \\
\hline 19 & Dec. broadl. forest & A, B & Dry dec. forest & 0.62 & $4.70(3.68)$ \\
\hline 20 & Evergr. broadl. forest & A, B & Rainforest & 12.76 & $10.40(9.12)$ \\
\hline 21 & Cropland & - & Agriculture & 13.13 & $15.48(30.01)$ \\
\hline 22 & Urban and build-up lands & - & & 0.73 & \\
\hline 23 & Cropland/nat. veg. mosaic & - & & 3.01 & \\
\hline
\end{tabular}

* A: equatorial, B: arid, C: warm temperate, D: snow, E: polar.

factor in Eq. (2) at time $t=1$ (in days) is assumed, lasting for 3,7 or 14 days, respectively (the values on the far right in the equations are the 24-hour rain rate which induces the pulse).

pulse $=\left\{\begin{array}{lll}11.19 \cdot e^{-0.805 \cdot t} & 1<t<3 ; & 1-5 \frac{\mathrm{mm}}{\mathrm{day}} \\ 14.68 \cdot e^{-0.384 \cdot t} & 1<t<7 ; & 5-15 \frac{\mathrm{mm}}{\mathrm{day}} \\ 18.46 \cdot e^{-0.208 \cdot t} & 1<t<14 ; & >15 \frac{\mathrm{mm}}{\mathrm{day}}\end{array}\right.$

If the pulsing criterion is not fulfilled, then pulse is set to 1 . Thus the direct $\mathrm{SNO}_{\mathrm{x}}$ from the soil into the vegetation layer (lowest atmospheric layer containing vegetation of various types, e.g. grass, trees or shrubs) is calculated as the product of Eq. $(1 \mathrm{a}, \mathrm{b})$ and 2:

$\mathrm{SNO}_{\mathrm{x}}=$ pulse $\cdot F_{\text {soil }}\left(T, A_{\mathrm{w} / \mathrm{d}}\right.$, [fertilizer] $)$

Finally, $\mathrm{SNO}_{\mathrm{x}}$ is partly removed via dry deposition in the vegetation before it is released into the free troposphere, which is represented by a canopy reduction factor (CRF), calculated based on Jacob and Bakwin (1991) as:

$\mathrm{CRF}=\frac{e^{-k_{\mathrm{s}} \cdot \mathrm{SAI}}+e^{-k_{\mathrm{c}} \cdot \mathrm{LAI}}}{2}$ with $k_{\mathrm{s}}=8.75 \mathrm{~m} \mathrm{~m}^{-2}$ and $k_{\mathrm{c}}=0.24 \mathrm{~m} \mathrm{~m}^{-2}$ representing stomata and cuticle absorptivity constants. SAI is the stomatal area index (ratio of stomatal area to leaf surface area) and LAI is the leaf area index (ratio of leaf surface to the geographical surface area). The calculation of CRF is originally based on ecosystem and season specific stomatal area indices as well as a monthly leaf area index map. $\mathrm{SNO}_{\mathrm{x}}{ }^{*}$ effectively released to the atmosphere is thus calculated by multiplying Eq. (5) with Eq. (4):

$\mathrm{SNO}_{\mathrm{x}}^{*}=\mathrm{CRF} \cdot \mathrm{SNO}_{\mathrm{x}}$

The $\mathrm{SNO}_{\mathrm{x}}$ in the YL95EMAC simulation prior to applying the CRF is depicted in Fig. 1.

\subsection{Compilation of measurements}

Yienger and Levy (1995) had far fewer measurements available when they developed their algorithm 15 years ago than there are today. They used data at 12 different sites in 3 ecosystems taken from 4 publications with 12 to 144 single events per site to calculate the exponential factor for the wet emissions between 10 and $30^{\circ} \mathrm{C}$ (see Eq. 1a), and measurements from 24 sites in 6 of their ecosystems taken from 


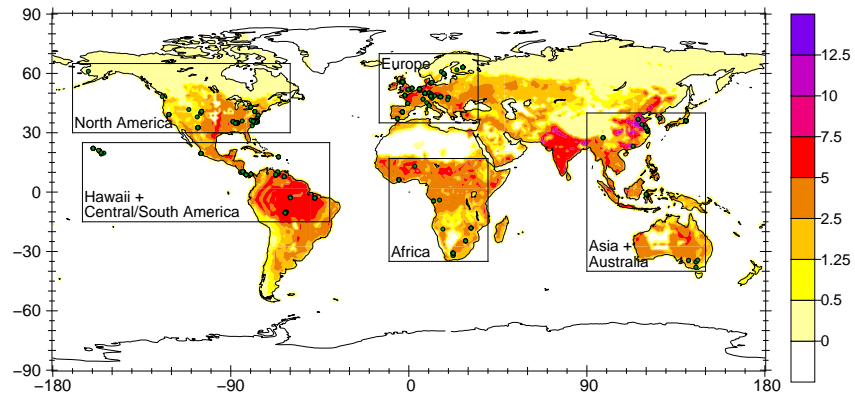

Fig. 1. $\mathrm{SNO}_{\mathrm{x}}$ flux in the YL95EMAC simulation (in $\mathrm{ngm}^{-2} \mathrm{~s}^{-1}$ ), along with the locations of measurements (dots) and the regions referred to in Sect. 3.6.1.

15 publications (plus two additional unpublished sites) were used to calculate the other emission factors under wet conditions. For the dry emission factors they used 9 sites in one ecosystem (grassland) taken from 7 publications (including two unpublished sites). For one ecosystem (dry deciduous forest), they did not indicate where the data comes from and for the others the dry emission factor is calculated as one third of the wet emission flux which is applied above $30^{\circ} \mathrm{C}$ (see Eq. 1a), which gives $A_{\mathrm{d}}=\frac{21.97}{3} A_{\mathrm{w}} \approx 7.3 \cdot A_{\mathrm{w}}$. Based on one measurement in rice paddies (Galbally et al., 1987), YL95 assumed reduced agricultural emissions by a factor of 30 in the whole agricultural area of eastern Asia and half the agricultural area of east and central India. This reduction is highly debatable, and the sensitivity of the results to this reduction is discussed in Sect. 5.

We have compiled, building on Stehfest and Bouwman (2006), a dataset consisting of 112 articles with 583 field measurements of $\mathrm{SNO}_{\mathrm{x}}$ covering the period from 1976 to 2010, with 367 measurements during the simulation period. There are clear spatial gaps in the measurements, e.g. over Russia and the Middle East, which can be seen by the distribution of the measurement locations in Fig. 1.

We employ a more recent landcover system, based on the MODIS satellite data (Friedl et al., 2006) and combine this for some landcover classes with the Koeppen main climate classes (Kottek et al., 2006) listed in Table 1, which doubles the number of landcover classes used in our study compared to YL95 and YL95EMAC. In order to compare to YL95EMAC, we associated the most similar ecosystem used in YL95 with the landcover class after Friedl et al. (2006) for each individual measurement based on the given description. In the following text, we refer to landcovers in the A and B (and some of the C) climates as "warm", and landcovers in the rest of the $\mathrm{C}$ and in the D and E climates as "cold". We also give the landcover ID used in Table in brackets, whenever specific landcovers are referred to below. The compilation and additional information like soil properties and the literature references are made available in the electronic supplement.

\section{All Landcovers}

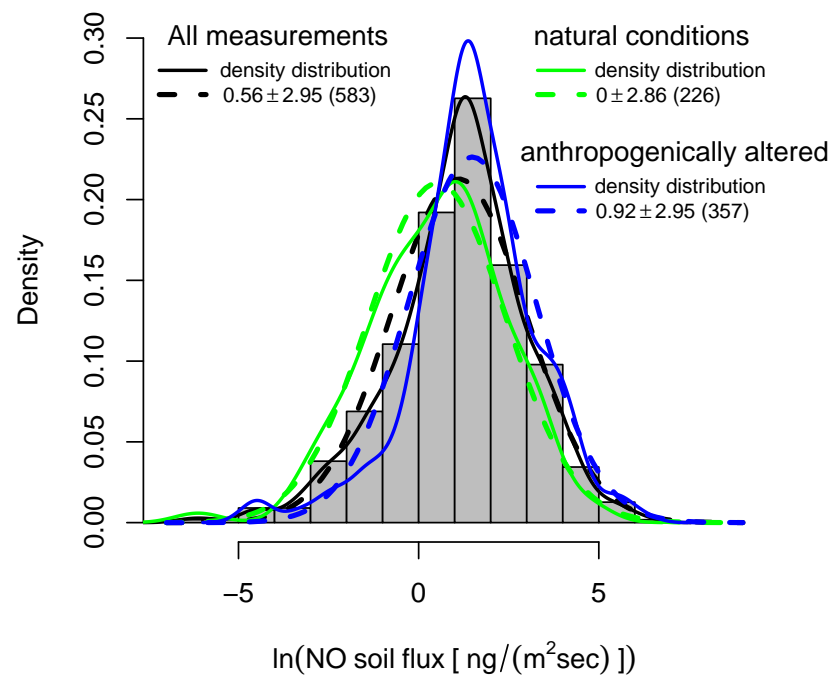

Fig. 2. Logarithmic histogram and probability density function (solid line) of all measured $\mathrm{SNO}_{\mathrm{x}}$ in the compilation with standard distribution, calculated mean and standard deviation. Black lines: all measurements, green lines: under natural conditions only, blue lines: anthropogenically altered only. The dashed lines are the calculated standard distributions. Number of measurements are in brackets.

The range of measured $\mathrm{SNO}_{\mathrm{x}}$ spans from -6.89 to $547 \mathrm{ng} \mathrm{m}^{-2} \mathrm{~s}^{-1}$ in the whole compilation with a nearly $\log$ normal distribution (Fig. 2), which is quite common for natural processes. There are 23 measured fluxes less than 0 , and 8 measured fluxes equal to 0 . The deviation introduced by ignoring these values is very small (see Sect. 3.6). We write the log-normal means and standard deviations for example as $3.67_{-2.45}^{+7.35}$, rather than in the exponential form $e^{1.3 \pm 1.1}$. By classifying the compiled measurements using the MODIS landcover combined with the Koeppen main climate classes, there are measurements in 13 of the 24 new landcover classes (Table 1). As can be seen in Fig. 3 the log-normal distribution again matches the distribution of the measurements in individual ecosystems, when we ignore all fluxes that are equal to or less than zero. In cold open shrubland (8) there was only one measurement, therefore no histogram can be shown for it.

Due to the large variations in the measured $\mathrm{SNO}_{\mathrm{x}}$ fluxes and the coarse spatial model resolution in AC-GCMs, we will use the full compilation of measurements for optimizing the calculation of $\mathrm{SNO}_{\mathrm{x}}$ fluxes, rather than only the measured fluxes that were carried out during our simulation period (underlying this is an assumption of a relatively stable climate with annually varying weather and soil conditions during the measurement period). The compilation contains 219 measurements in agricultural lands, 226 measurements under more or less "undisturbed" or "natural" 

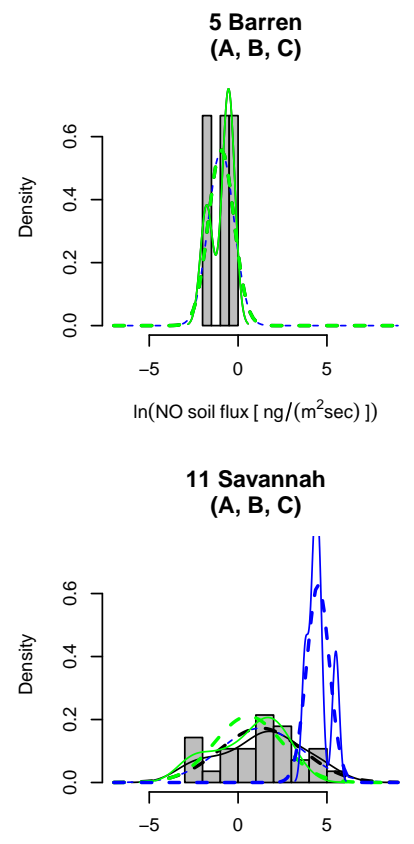

$\ln \left(\right.$ NO soil flux $\left.\left[\mathrm{ng} /\left(\mathrm{m}^{2} \mathrm{sec}\right)\right]\right)$

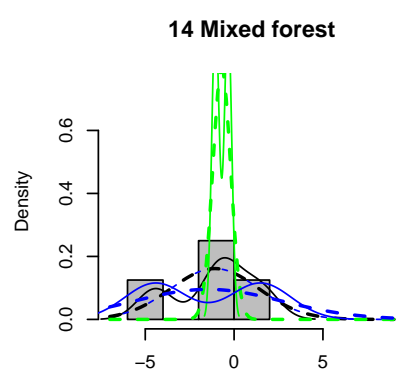

$\ln \left(\mathrm{NO}\right.$ soil flux $\left.\left[\mathrm{ng} /\left(\mathrm{m}^{2} \mathrm{sec}\right)\right]\right)$

19 Deciduous broadleaved forest (A, B)

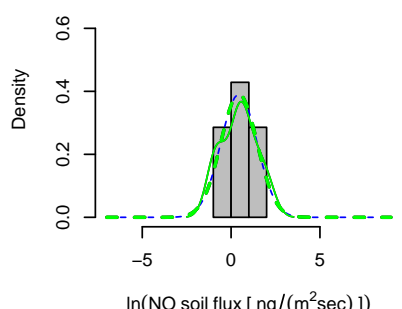

6 Closed shrubland

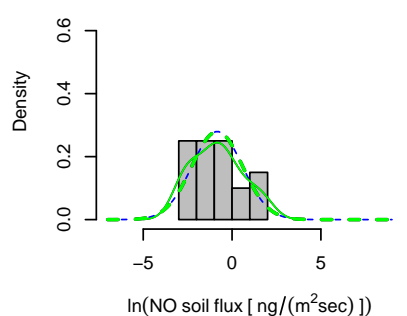

12 Grassland

$(\mathrm{A}, \mathrm{B}, \mathrm{C})$

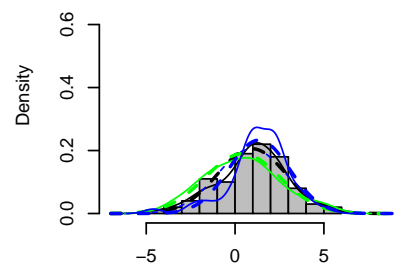

In(NO soil flux $\left.\left[\mathrm{ng} /\left(\mathrm{m}^{2} \mathrm{sec}\right)\right]\right)$

16 Deciduous broadleaved forest (C, D, E)

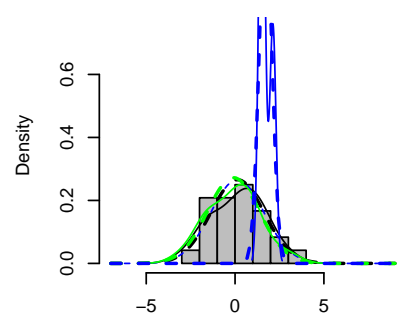

$\ln \left(\right.$ NO soil flux $\left.\left[\mathrm{ng} /\left(\mathrm{m}^{2} \mathrm{sec}\right)\right]\right)$

20 Evergreen broadleaved forest (A, B)

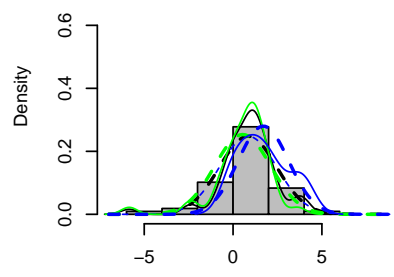

In(NO soil flux $\left.\left[\mathrm{ng} /\left(\mathrm{m}^{2} \mathrm{sec}\right)\right]\right)$
10 Savannah

(D, E)

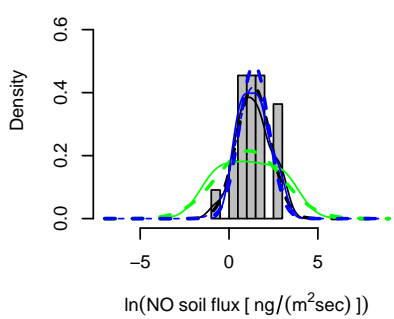

13 Woody savannah

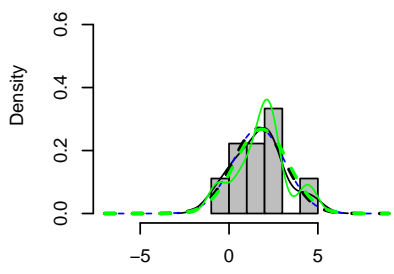

$\ln \left(\right.$ NO soil flux $\left[\mathrm{ng} /\left(\mathrm{m}^{2} \mathrm{sec}\right)\right]$ )

17 Evergreen needleleaved forest

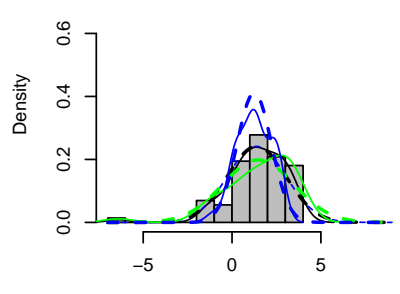

$\ln \left(\right.$ NO soil flux $\left.\left[\mathrm{ng} /\left(\mathrm{m}^{2} \mathrm{sec}\right)\right]\right)$

21 Cropland

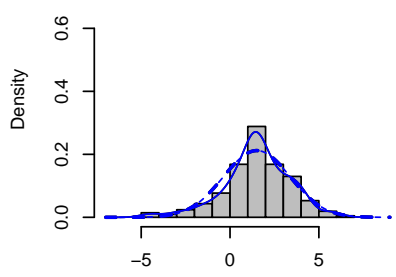

In(NO soil flux [ $\left.\mathrm{ng} /\left(\mathrm{m}^{2} \mathrm{sec}\right)\right]$ )

Fig. 3. Logarithmic histogram and probability density function per MODIS landcover and Koeppen main climate class (in brackets) of measured $\mathrm{SNO}_{\mathrm{x}}$ in the compilation. Color and line type as in Fig. 2.

conditions and 138 measurements for anthropogenically altered conditions in the non-agricultural landcovers. Anthropogenic alterations include fertilizer application, irrigation, liming, clearcutting and other perturbations. The measurements under non-agricultural land with anthropogenic influence $\left(4.29_{-3.38}^{+16.08}\right)$ are, according to the Kolmogorov-Smirnov test with $p<10^{-3}$, significantly higher than under unperturbed natural conditions $\left(1.68_{-1.43}^{+9.52}\right)$. Therefore wherever enough measurements were available, we use only the unperturbed measurements to calibrate our new emission factors, whereas we used all the measurements whenever too few were available. 
All ecosystems

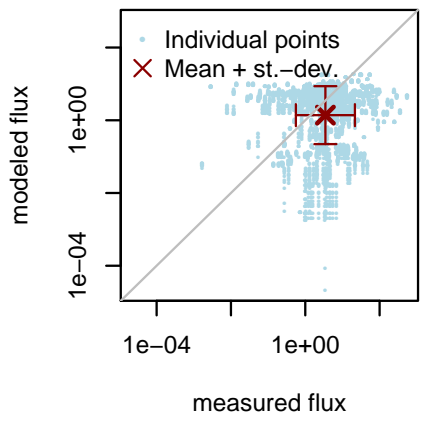

Woodland

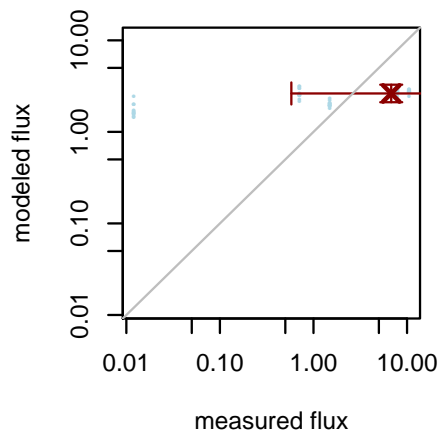

Drought deciduous forest

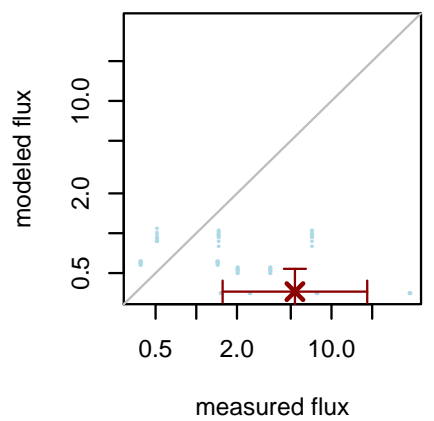

Tundra

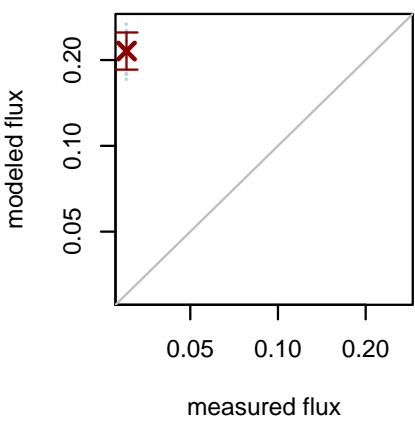

Deciduous forest

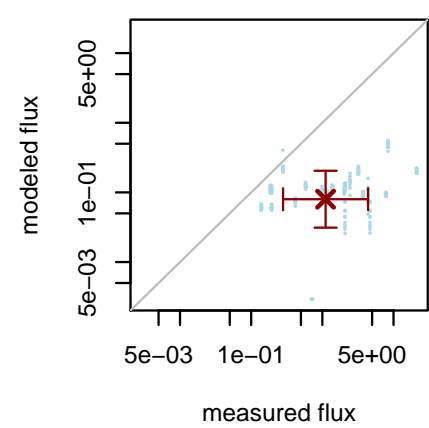

Rainforest

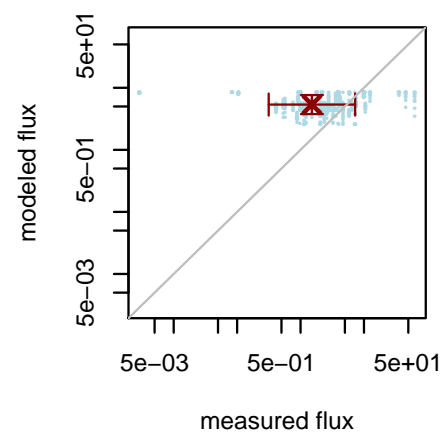

\section{Grassland}

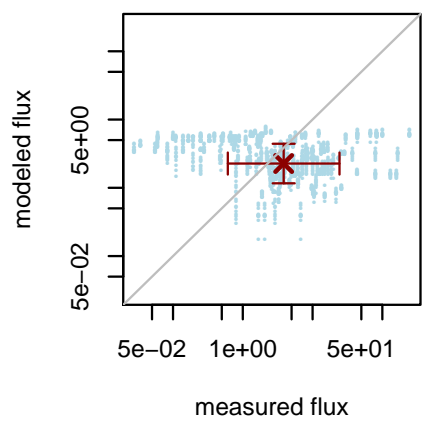

Coniferous forest

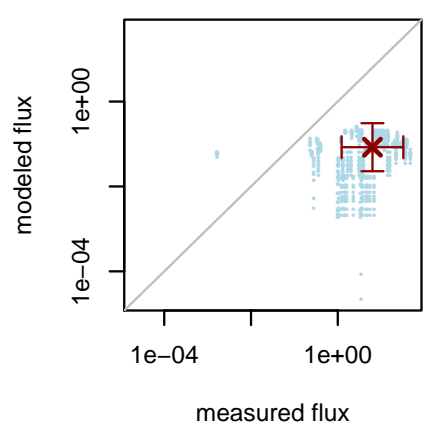

Agriculture

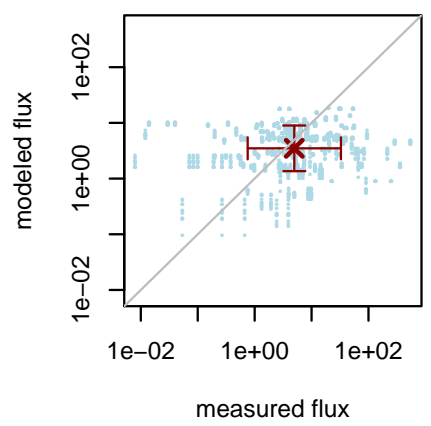

Fig. 4. Scatterplot of simulated $\mathrm{SNO}_{\mathrm{x}}$ in YL95EMAC for each corresponding period of the year versus each measurement along with the mean values and standard deviations.

\section{Emission model updates}

In Fig. 4 we compare the simulated flux of YL95EMAC with the measured fluxes in our compilation of measurements for each ecosystem, and Table 2 gives the mean values for each ecosystem. From this it is obvious that the flux from each ecosystems (except tundra and rainforest) as well as the global simulated flux is underestimated by the algorithm, and an improvement is necessary. All of the fluxes in this section are without considering the CRF, since this would introduce another uncertainty. Furthermore, almost all measurements in our compilation were chamber measurements, for which the canopy interaction does not play a significant role.

In the following sections we introduce the improvements which we implemented in the calculation of the $\mathrm{SNO}_{\mathrm{x}}$ flux in our model and discuss the changes which were caused by these improvements. We discuss the change in the pulsing routine first, since this affects all our new simulations beyond YL95EMAC. The change in the underlying landcover map and the change in how fertilizer application is dealt with cannot readily be treated separately and are discussed in one step (LC). The LC case is also used for considering the effects of 
Table 2. Measured and simulated $\mathrm{SNO}_{\mathrm{x}}$ for the YL95EMAC ecosystems (in $\mathrm{ng} \mathrm{m}^{-2} \mathrm{~s}^{-1}$ ). Measurements are taken from our compilation (numbers per ecosystem in brackets) and the simulated $\mathrm{SNO}_{\mathrm{x}}$ values are for the corresponding period of each simulated year.

\begin{tabular}{lrrr}
\hline Ecosystem & $N$ & measured & YL95EMAC \\
\hline Tundra & $11(1)$ & $0.03_{-0}^{+0}$ & $0.22_{-0.03}^{+0}$ \\
Grassland & $1695(156)$ & $3.85_{-3.48}^{+20.48}$ & $2.27_{-1.1}^{+12.05}$ \\
Woodland & $55(5)$ & $6.77_{-6.19}^{+72.29}$ & $2.63_{-0.52}^{+28.06}$ \\
Deciduous forest & $227(22)$ & $1.11_{-0.83}^{+3.29}$ & $0.08_{-0.05}^{+0.24}$ \\
Coniferous forest & $759(71)$ & $6.3_{-5}^{+26.07}$ & $0.08_{-0.06}^{+0.35}$ \\
Drought deciduous forest & $117(11)$ & $5.37_{-3.8}^{+13.01}$ & $0.36_{-0.12}^{+0.88}$ \\
Rainforest & $552(51)$ & $1.51_{-1.2}^{+5.75}$ & $5.36_{-1.59}^{+20.39}$ \\
Agriculture & $2111(196)$ & $4.97_{-4.22}^{+27.81}$ & $3.49_{-2.13}^{+19.54}$ \\
\hline All ecosystems & $5527(513)$ & $3.48_{-2.92}^{+18.2}$ & $1.38_{-1.16}^{+7.23}$ \\
\hline
\end{tabular}

resolution, before going on to the other individual developments.

\subsection{Pulsing}

In the YL95EMAC algorithm as implemented previously in EMAC the amount of precipitation to initiate the pulsing was queried every model timestep; therefore the pulsing hardly ever reached its maximum range of values, and contributes only $3 \%$ to the total $\mathrm{SNO}_{\mathrm{x}}$ in the YL95EMAC simulation. From the LC simulation onwards, we check the precipitation of the last $24 \mathrm{~h}$ only once a day at 00:00 UTC. As a result, the fraction attributed to pulsing increases to $17 \%$ (Table 3 ). Our new result is in the range of the 10-22\% proposed by Davidson (1992) and, compared to the previous YL95EMAC setup, it is much closer to the $24 \%$ originally simulated by YL95.

Nevertheless, we note that this is a very crude implementation. In the literature some measurements show small pulses (Garcia-Montiel et al., 2003), while others show much larger pulses (Davidson et al., 1991). Too much rain could also reduce the diffusity of the soil (Rondón et al., 1993), which would reduce the strength of the pulse with strong precipitation events. Finally other events which can also generate pulses, like fire or plowing (Sanhueza, 1997), are not yet considered in our model.

\subsection{Ecosystem/landcover (LC)}

Instead of using the twelve ecosystems originally introduced by YL95, we use the 18 MODIS landcover classes (Friedl et al., 2006) for the year 2000 and combine them with the main climates of the Koeppen climate classification (Kottek et al., 2006) to yield a new total of 24 landcover types (Table 1) with the emission factors listed in Table 3.
Table 3. The original (YL95) emission factors and the soil biogenic NO emissions calculated with the old ecosystems (YL95EMAC) and with the new landcover (LC). When not shown, standard deviations are less than or equal to 0.001 .

\begin{tabular}{|c|c|c|c|c|c|c|c|}
\hline \multirow[b]{2}{*}{ ID } & \multicolumn{2}{|c|}{ Emission factors } & \multicolumn{5}{|c|}{ Emission $\left[\frac{\operatorname{Tg}(\mathrm{N})}{\text { year }}\right]$} \\
\hline & wet & dry & YL95EM & $\mathrm{AC}^{*}$ & & $\mathrm{LC}^{*}$ & \\
\hline 0 & 0 & 0 & 0 & & 0 & & \\
\hline 1 & 0 & 0 & 0 & & 0 & & \\
\hline 2 & 0 & 0 & 0 & & 0 & & \\
\hline 3 & 0 & 0 & 0 & & 0 & & \\
\hline 4 & 0 & 0 & 0 & & 0 & & \\
\hline 5 & 0 & 0 & 0 & & 0 & & \\
\hline 6 & 0 & 0 & 0 & & 0 & & \\
\hline 7 & 0 & 0 & 0 & & 0 & & \\
\hline 8 & 0.05 & 0.37 & 0.02 & $(3 \%)$ & $0.03 \pm$ & 0.002 & $(17 \%)$ \\
\hline 9 & 0.05 & 0.37 & & & 0.002 & & $(18 \%)$ \\
\hline 10 & 0.05 & 0.37 & & & 0.03 & & $(20 \%)$ \\
\hline 11 & 0.36 & 2.65 & $3.0 \pm 0.05$ & $(2 \%)$ & $1.65 \pm$ & 0.03 & $(16 \%)$ \\
\hline 12 & 0.36 & 2.65 & & & $1.17 \pm$ & 0.02 & $(19 \%)$ \\
\hline 13 & 0.17 & 1.44 & $0.45 \pm 0.01$ & $(3 \%)$ & $0.61 \pm$ & 0.01 & $(15 \%)$ \\
\hline 14 & 0.03 & 0.22 & 0.02 & $(2 \%)$ & 0.03 & & $(16 \%)$ \\
\hline 15 & 0.03 & 0.22 & & & 0.02 & & $(16 \%)$ \\
\hline 16 & 0.03 & 0.22 & & & 0.01 & & $(17 \%)$ \\
\hline 17 & 0.03 & 0.22 & & & 0.002 & & $(17 \%)$ \\
\hline 18 & 0.03 & 0.22 & 0.03 & $(3 \%)$ & 0.02 & & $(18 \%)$ \\
\hline 19 & 0.06 & 0.4 & 0.09 & $(3 \%)$ & 0.02 & & $(15 \%)$ \\
\hline 20 & 2.6 & 8.6 & $1.6 \pm 0.1$ & $(3 \%)$ & $2.33 \pm$ & 0.05 & $(12 \%)$ \\
\hline 21 & 0.36 & - & $4.03 \pm 0.04$ & $(3 \%)$ & $3.84 \pm$ & 0.40 & $(20 \%)$ \\
\hline 22 & 0.36 & - & & & $0.25 \pm$ & 0.01 & $(17 \%)$ \\
\hline 23 & 0.36 & - & & & $0.95 \pm$ & 0.06 & $(18 \%)$ \\
\hline sum & & & $9.24 \pm 0.16$ & $(3 \%)$ & $10.95 \pm$ & 0.48 & $(17 \%)$ \\
\hline
\end{tabular}

* pulsing fraction in brackets.

$\mathrm{SNO}_{\mathrm{x}}$ increases from $9.24 \pm 0.16 \mathrm{Tg}(\mathrm{N}) \mathrm{yr}^{-1}$ to $10.95 \pm 0.48 \mathrm{Tg}(\mathrm{N}) \mathrm{yr}^{-1}$ due to the new landcover map. We simulate a small increase in "natural" ecosystems (ID 0-20 in Table 1), changing from $5.21 \mathrm{Tg}(\mathrm{N}) \mathrm{yr}^{-1}$ to $5.91 \mathrm{Tg}(\mathrm{N}) \mathrm{yr}^{-1}$ and a larger increase in "anthropogenic" ecosystems (ID 2123) from 4.03 to $5.04 \mathrm{Tg}(\mathrm{N}) \mathrm{yr}^{-1}$. The geographical distribution of anually simulated $\mathrm{SNO}_{\mathrm{x}}$ also changes, in particular with:

- Increased emissions over Europe, central USA, Eastern Asia and India (Fig. 5), especially due to the treatment of fertilizer (see Sect. 3.4); and

- Lower emissions over large parts of Australia, the southern Arabian peninsula and Somalia, which was prescribed as grassland in YL95EMAC, while these regions are now dominated by shrublands.

If we were to apply the reduced emissions in the "riceproducing areas", this would introduce unrealistic straight borders at $35^{\circ} \mathrm{N}$ and $60^{\circ} \mathrm{E}$ with emissions reduced by $1.24 \mathrm{Tg}(\mathrm{N}) \mathrm{yr}^{-1}$ (see Sects. 4 and 5 for discussion). 


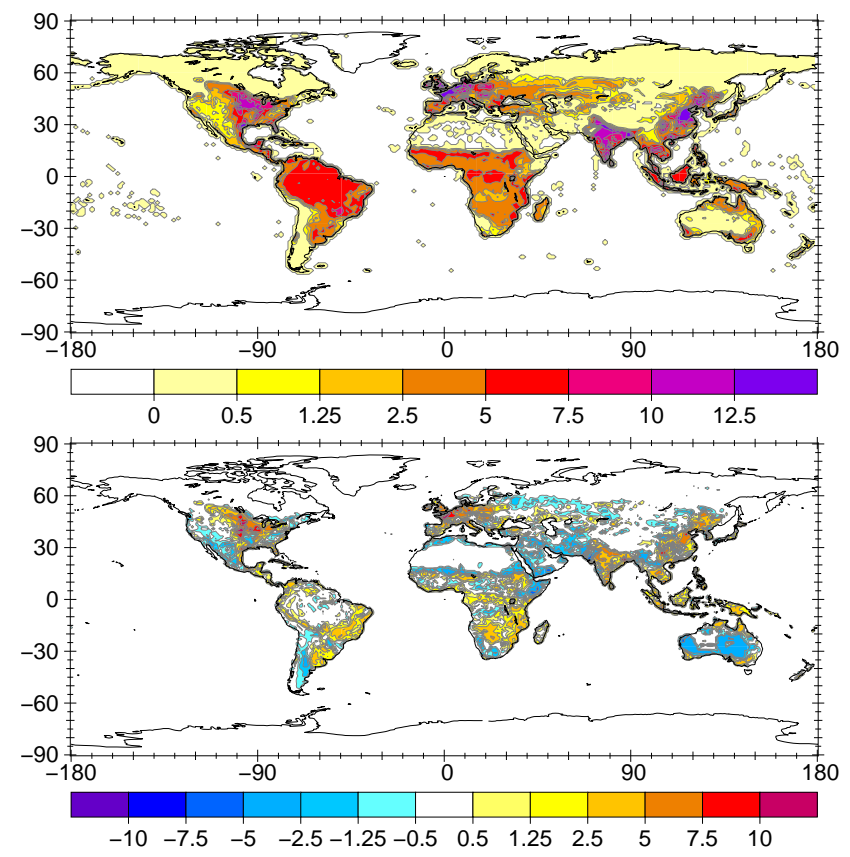

Fig. 5. Averaged $\mathrm{SNO}_{\mathrm{x}}$ flux in the whole simulation period (in $n \mathrm{n} \mathrm{m}^{-2} \mathrm{~s}^{-1}$ ) for the LC simulation (upper panel) and the change compared to the YL95EMAC simulation (lower panel).

\subsection{Influence of model resolution}

The simulations considered here are at a relatively high resolution, without the computationally expensive chemical processes in the atmosphere. When they are included, the model is usually run at a lower horizontal resolution. To investigate the influence of the resolution on $\mathrm{SNO}_{\mathrm{x}}$ we performed three additional simulations at T21 $\left(\sim 5.6 \times 5.6^{\circ}\right)$, T42 $\left(\sim 2.8 \times 2.8^{\circ}\right)$ and T63 $\left(\sim 1.9 \times 1.9^{\circ}\right)$. The effect of the resolution is depicted in Fig. 6.

The fraction of $\mathrm{SNO}_{\mathrm{x}}$ from rain induced pulses increases with a finer model resolution. Since in a coaser horizontal model resolution the convective precipitation is dispersed over a larger area, this leads to weaker pulses and less likelihood of reaching the pulsing threshold.

The general increase of the emission rate at a finer resolution is due to the exponential dependence on the temperature in the calculation of the wet emission flux. Although the temperature of one gridbox in the lower resolution simulation will roughly equal the mean temperature of the corresponding set of gridboxes in the high resolution simulation, the peak temperatures will be greater at higher resolution, so that due to the exponential function, $\mathrm{SNO}_{\mathrm{x}}$ will also be higher in the finer resolution simulation. One possibility to reduce the underestimation in the coarser resolution simulations would be to scale either all the emission factors or the emission flux by the ratio of the annual emission flux in the T106 simulation to the coarse resolution simulations (Table 4).

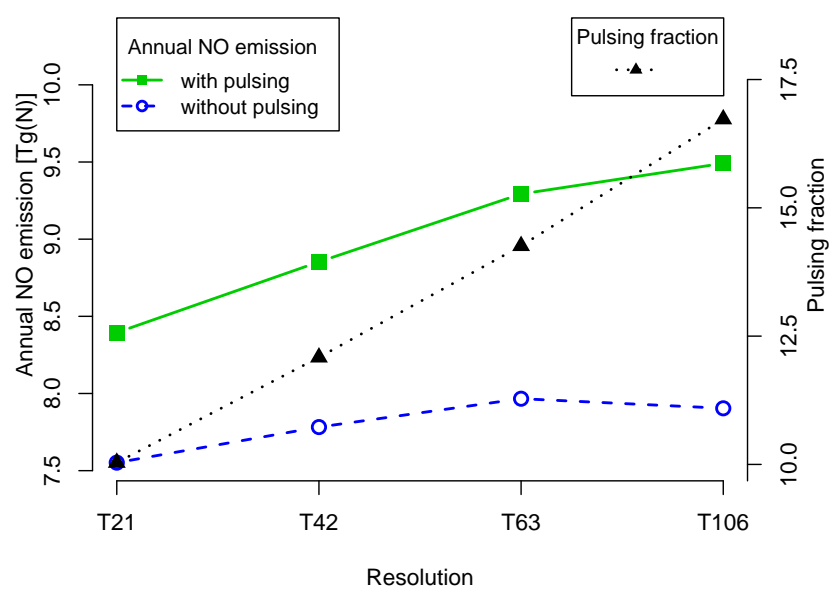

Fig. 6. Change of soil biogenic NO emission with pulsing (green boxes), without pulsing (blue circles), and the pulsing fraction (triangles) for the LC simulation at four different horizontal resolutions.

Table 4. Relative annual underestimation of $\mathrm{SNO}_{\mathrm{x}}$ in the coarser simulations compared to the T106 resolution of the YL95EMAC and LC simulation. And the remaining deviation after scaling the emission factors by the initial underestimation. The last column lists the global area defined as wet in $10^{6} \mathrm{~km}^{2}$ (T106: $111.8 \times 10^{6} \mathrm{~km}^{2}$ ).

\begin{tabular}{l|rr|rr|r}
\hline & $\begin{array}{c}\text { YL95EMAC } \\
\text { initial } \\
\text { underestimation }\end{array}$ & \multicolumn{2}{|c|}{$\begin{array}{c}\text { LC } \\
\text { remaining } \\
\text { underestimation }\end{array}$} & $\begin{array}{r}\text { wet area } \\
{\left[10^{6} \mathrm{~km}^{2}\right]}\end{array}$ \\
\hline $\mathrm{T} 21$ & $11.8 \%$ & $4.6 \%$ & $13.1 \%$ & $5.6 \%$ & 108.6 \\
$\mathrm{~T} 42$ & $4.3 \%$ & $2.1 \%$ & $7.2 \%$ & $3.3 \%$ & 110.0 \\
$\mathrm{~T} 63$ & $2.1 \%$ & $1.8 \%$ & $2.3 \%$ & $2.0 \%$ & 111.1 \\
\hline
\end{tabular}

Scaling the emission factors results in a notable improvement (Table 4) but still results in an underestimation, since the area of soils defined as wet increases slightly with increasing resolution and other unresolved non-linearities influence the simulation.

\subsection{Fertilizer induced NO emission (LC + FIE)}

In YL95EMAC the ecosystem map was overlaid with the cultivation index by Bouwman et al. (2002) and used the same amount of applied fertilizer for each year, from which a certain fraction $(0.7 \%)$ was emitted as FIE during the growing season. However, since agriculture is already defined in the ecosystem map based on Olson (1992), but was not considered as a separate ecosystem in YL95EMAC, effectively some fraction of the emitting gridbox is neglected (otherwise some fraction would have been double-counted). Therefore $\mathrm{SNO}_{\mathrm{x}}$ from model gridboxes with a fraction of agriculture in the ecosystem map was underestimated in YL95EMAC. This can also be seen if one sums up the ecosystem areas used for the calculation of the emission flux (values in brackets of 
column "YL95EMAC" in Table 1), which gives a total world surface area of $504 \times 10^{6} \mathrm{~km}^{2}$, less than the actual surface area of $510 \times 10^{6} \mathrm{~km}^{2}$.

The amount of globally consumed fertilizer increased within the period of our simulation by $18 \%$, based on an analysis by the United Nations Environment Programme (UNEP, http://geodata.grid.unep.ch). Therefore we use yearly varying fertilizer application based on the country based FAO fertilizer consumption rate provided by UNEP, and assume that the fertilizer is applied on the area of the last three landcover classes in Table 1 during the growing season as described in YL95. Since using this method results in unrealistic amounts of fertilizer usage for the Lesser Antilles and the islands east of Madagascar (up to $34,790 \mathrm{~kg}(\mathrm{~N}) \mathrm{ha}^{-1} \mathrm{yr}^{-1}$ ), we assumed an upper limit of $500 \mathrm{~kg}(\mathrm{~N}) \mathrm{ha}^{-1} \mathrm{yr}^{-1}$, which is high but should be viable, given that fertilizer applications up to 378$524 \mathrm{~kg}(\mathrm{~N}) \mathrm{ha}^{-1} \mathrm{yr}^{-1}$ have been reported (Richter and Roelcke, 2000). This approach is still not very accurate, since for example fertilizer is not spatially and temporally distributed evenly over large countries like China (Ju et al., 2004), and different crop types receive different amounts of fertilizer. However, the information needed to distribute the fertilizer by crop type is presently not available, thus we can only make modest improvements, such as the annually varying fertilizer application rates.

Yienger and Levy (1995) originally assumed a fraction of $2.5 \%$ of the applied fertilizer to be lost as NO. Based on our compilation of measurements our best estimate (arithmetic mean) of FIE is $1 \pm 2.1 \%$, therefore we set the FIE to $1 \%$ in our optimized simulation, which gives a global emission of $1.27 \mathrm{Tg}(\mathrm{N}) \mathrm{yr}^{-1}$ induced by fertilizer application, instead of 3.17 with an FIE of $2.5 \%$. Thus we have reduced the global NO emissions by $1.9 \mathrm{Tg}(\mathrm{N}) \mathrm{yr}^{-1}$ by reducing the FIE in our simulation from $2.5 \%$ to $1 \%$. The reduction is mainly located over the central USA, Europe, northeast Asia and India.

Our estimated fertilizer fraction emitted as $\mathrm{SNO}_{\mathrm{x}}$ is higher than the value of $0.55 \%$ calculated by Stehfest and Bouwman (2006) and the previous value by Bouwman et al. (2002) of $0.7 \%$, which contributed $0.7 \mathrm{Tg}(\mathrm{N}) \mathrm{yr}^{-1}$ to the total flux in YL95EMAC (Ganzeveld et al., 2006). The total annual $\mathrm{SNO}_{\mathrm{x}}$ from agriculture in the LC+FIE simulation of $3.13 \operatorname{Tg}(\mathrm{N})$ is higher than the estimate by Bouwman et al. (2002) and Stehfest and Bouwman (2006) of 1.8 and $1.6 \operatorname{Tg}(\mathrm{N})$, respectively, but our value is within the large range of uncertainty given by Stehfest and Bouwman (2006) ( $-80 \%$ and $+406 \%$ for the $95 \%$ confidence interval).

Finally the reduction of $\mathrm{SNO}_{\mathrm{x}}$ in the "rice-producing areas" is debatable (see Sect. 5). If we would reduce the emissions there, we would decrease the emissions by $0.81 \operatorname{Tg}(\mathrm{N}) \mathrm{yr}^{-1}$.

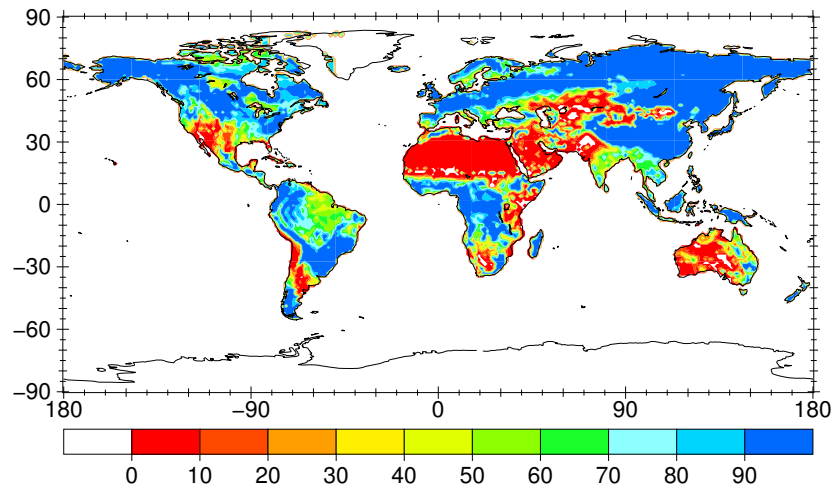

Fig. 7. Percentage of wet soil conditions during the whole simulation period.

\subsection{Soil moisture state ( LC + FIE + VSM)}

Yienger and Levy (1995) used the precipitation history to distinguish between the dry and wet soil conditions. In YL95EMAC the water column in the soil as described by Roeckner et al. (2003) was used instead. Since the simulation of soil moisture has improved substantially over the last decade, we can now make use of the volumetric soil moisture content, which can be calculated with the help of the root depth (S. Hagemann, personal communication, 2009). We set the threshold for dry vs. wet conditions to $15 \%$ volumetric soil moisture content, which is for an average soil between the field capacity (amount of water that can be held by the soil against the gravitational force) and the permanent wilting point (below which plants can not take up the water anymore). However, for pure sand, $15 \%$ is more than can be held against the gravitational force, whereas in pure clay $15 \%$ is even less moisture then the permanent wilting point (Scheffer and Schachtschabel, 2002). Figure 7 shows how often the soil was defined as wet during the simulation period.

This modification has a major impact on the classes warm savannah (11), warm grassland (12) and woody savannah (13), with a decrease of annual $\mathrm{SNO}_{\mathrm{x}}$ flux by $0.41,0.42$, and $0.11 \mathrm{Tg}(\mathrm{N})$, respectively. Since these landcover classes are mostly present in the Sahel region, eastern Africa and southern USA/northern Mexico, the emissions from those regions are affected most. In the other landcover classes the emissions are reduced by less than $0.01 \mathrm{Tg}(\mathrm{N}) \mathrm{yr}^{-1}$. This includes the cropland classes, which do not include an explicit dependence on the soil moisture, since it is assumed that due to irrigation the soil moisture is relatively constant and normally in the wet regime, although this assumption could possibly be improved in future studies. As a result of these changes, the global annual flux in the LC+FIE + VSM simulation is $8.08 \mathrm{Tg}(\mathrm{N}) \mathrm{yr}^{-1}$.

As far as we are aware, the soil moisture of GCMs has generally not yet been carefully evaluated; this represents an 
important uncertainty that may degrade the quality of our results. Note that there may be considerable differences in the formulation of the soil moisture in other GCMs, and the distinction into wet and dry conditions would be an interesting facet of the algorithm to examine and possibly improve in a future multi-GCM intercomparison.

\subsection{Emission factors (YL95/SL11)}

For each individual measurement in our compilation we calculated the emission factor for the appropriate period of the whole simulation (individually for each year of the simulation, then determining the mean emission factor from these) as described below. In order to reduce the statistical error we used monthly averages instead of averages only over those days for which measurements were available.

Since we have only the total $\mathrm{SNO}_{\mathrm{x}}$ for each measurement and do not have time series of the measurements, accompanied with time series of temperature and soil moisture it is impossible to calculate the emission factors analytically. Note that the wet and dry emission factors cannot be estimated separately due to the lack of time series data of the measured $\mathrm{SNO}_{\mathrm{x}}$ flux. We therefore keep the ratio between the dry and wet factor constant at 7.3 (rainforest: 3.3), as in the algorithm by YL95. This allows us to use a simple linear fit for the emission factor, which we compute as the ratio of the measured flux to the flux calculated with the old emission factors. For the geometric mean we calculated the new emission factors for each landcover class $\left(A_{\mathrm{w} / \mathrm{d}}\right)$ according to Eq. (6). We weight each calculated emission factor by the duration of the experimental period in $d$ days.

$A_{\mathrm{w} / \mathrm{d}}=e^{\frac{\sum_{i=1}^{N}\left(\log \left(A_{\mathrm{w} / \mathrm{d}, i}\right) \cdot d_{i}\right)}{\sum_{i=1}^{N} d_{i}}}$

with $A_{\mathrm{w} / \mathrm{d}, i}$ being the wet and dry emission factors for each measurement $i$, and $N$ is the number of measurements per landcover. The calculation of the arithmetic mean was also weighted by the duration of the measurement.

For landcover classes with both anthropogenically altered and unperturbed measurements, we calculate the emission factors from unperturbed measurements only. In woody savannah using all measurements decreased the emissions by $0.44 \operatorname{Tg}(\mathrm{N})$ compared to unperturbed measurements only. This decrease is nearly compensated by slightly increased emissions from warm savannah (11), evergreen needleleaved forest (18) and warm evergreen broadleaved forest (20). The wet emission factors for unperturbed and altered conditions are depicted in Fig. 8.

To give a potential upper limit for $\mathrm{SNO}_{\mathrm{x}}$, we also calculated the emissions based on arithmetically averaged emisson factors (Table 6), including also the negative and zero fluxes. The total global $\mathrm{SNO}_{\mathrm{x}}$ based on the arithmetic mean is $33.1 \pm 0.6 \mathrm{Tg}(\mathrm{N}) \mathrm{yr}^{-1}$ if we use unperturbed measurements only to calibrate the emission factors. This is insignificantly larger than the value $32.9 \pm 0.6 \mathrm{Tg}(\mathrm{N}) \mathrm{yr}^{-1}$ which

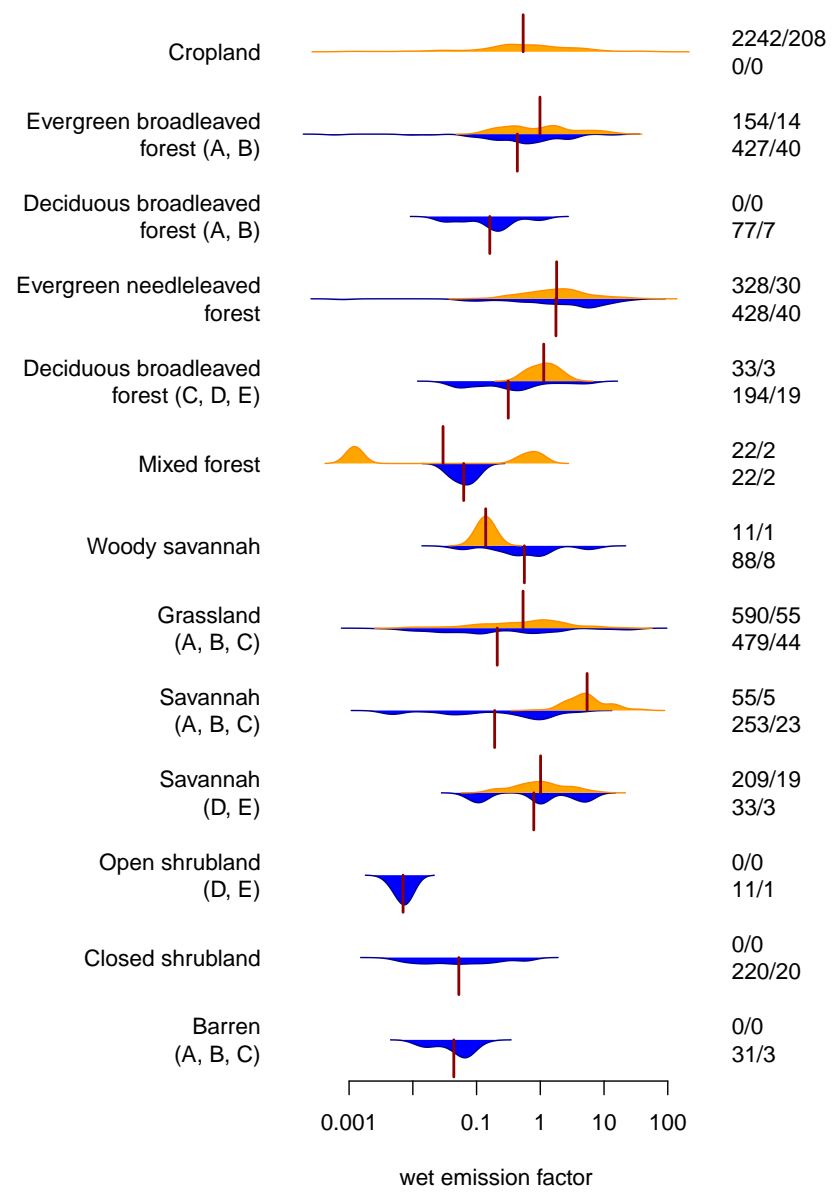

Fig. 8. Distribution of calculated emissions factors for anthropogenically altered (orange, above center line) and unperturbed (blue, below center line) measurements. The number of calculated emission factors and number of measurements per crop are given on the right side, respectively.

we compute when we also include anthropogenically altered measurements. The influence of omitting negative or zero fluxes increases the global total $\mathrm{SNO}_{\mathrm{x}}$ by only $1.18 \mathrm{Tg}(\mathrm{N})$ to $34.3 \pm 0.7 \mathrm{Tg}(\mathrm{N}) \mathrm{yr}^{-1}$ for the arithmetic mean. Given the large range of uncertainties for the emission factors, this indicates that omitting measurements less than or equal to zero in the calculation of the geometric mean only has a small effect. A much larger effect would result from reducing emission in the "rice-producing areas", which would decrease the emission by $4.8 \mathrm{Tg}(\mathrm{N}) \mathrm{yr}^{-1}$ in in the arithmetic mean calculation.

\subsubsection{Emission factors calculated by region}

As depicted in Fig. 1 we defined 5 regions with clusters of measurements. We abbreviate the regions as follows: EUR - Europe, NAM - North America, SAM - Central/South America + Hawaii, ASA - Asia and Australia and AFR Africa. Here we recompute the geometric mean of the emission factors separately for each region, using both the 
Table 5. The adopted (YL95/SL11) emission factors (geometric mean) and associated soil biogenic NO emissions. When not shown, standard deviations are less than or equal to 0.001 .

\begin{tabular}{|c|c|c|c|c|}
\hline \multirow[b]{2}{*}{ ID } & \multirow[b]{2}{*}{$\mathrm{N}$} & \multicolumn{2}{|c|}{ Emission factors } & \multirow{2}{*}{$\begin{array}{l}\text { Emission } \\
{\left[\frac{\mathrm{Tg}(\mathrm{N})}{\text { year }}\right]}\end{array}$} \\
\hline & & wet & dry & \\
\hline 0 & 0 & 0 & 0 & 0 \\
\hline 1 & 0 & 0 & 0 & 0 \\
\hline 2 & 0 & 0 & 0 & 0 \\
\hline 3 & 0 & 0 & 0 & 0 \\
\hline 4 & 0 & 0 & 0 & 0 \\
\hline 5 & $31(3)$ & $0.06_{-0.02}^{+0.02}$ & $0.43_{-}^{+} 0.15$ & $0.2 \pm 0.005$ \\
\hline 6 & $220(20)$ & $0.09_{-0.07}^{+0.31}$ & $0.65_{-}^{+} 2.24$ & 0.02 \\
\hline 7 & - & 0.09 & 0.65 & $0.33 \pm 0.01$ \\
\hline 8 & $11(1)$ & $0.01_{-0.00}^{+0.00}$ & $0.05_{-}^{+} 0.01$ & 0.005 \\
\hline 9 & - & 0.84 & 6.18 & $0.03 \pm 0.002$ \\
\hline 10 & $242(22)$ & $0.84_{-0.53}^{+1.42}$ & $6.18_{-3.88}^{+10.43}$ & $0.35 \pm 0.01$ \\
\hline 11 & $308(28)$ & $0.24_{-0.21}^{+1.71}$ & $1.76_{-1}^{+12.56}$ & $0.65 \pm 0.01$ \\
\hline 12 & 1069(99) & $0.42_{-0.35}^{+2.01}$ & $3.07_{-2.55}^{+14.83}$ & $0.9 \pm 0.02$ \\
\hline 13 & $99(9)$ & $0.62_{-0.30}^{+0.57}$ & $\begin{array}{l}5.28_{-}^{+}-2.52 \\
\end{array}$ & $2.29 \pm 0.03$ \\
\hline 14 & $44(4)$ & $0.03_{-0.03}^{+0.23}$ & $0.25_{-}^{+}-1.6 \overline{8}$ & $0.06 \pm 0.002$ \\
\hline 15 & - & 0.36 & 2.39 & $0.16 \pm 0.003$ \\
\hline 16 & $227(22)$ & $0.36_{-0.27}^{+1.12}$ & $\begin{array}{l}2.39_{-}^{+} 7.44 \\
1.81\end{array}$ & $0.11 \pm 0.003$ \\
\hline 17 & - & 0.35 & 2.35 & $0.02 \pm 0.002$ \\
\hline 18 & $756(70)$ & $1.66_{-1.36}^{+7.49}$ & $12.18_{-9.97}^{+54.86}$ & $0.75 \pm 0.03$ \\
\hline 19 & $77(7)$ & $0.08_{-0.05}^{+0.30}$ & $0.62_{-0.19}^{+} 1.03$ & 0.02 \\
\hline 20 & $581(54)$ & $0.44_{-0.37}^{+2.27}$ & $2.47_{-2.02}^{+11.17}$ & $0.38 \pm 0.009$ \\
\hline 21 & $2242(208)$ & $0.57_{-0.46}^{+2.56}$ & - & $3.25 \pm 0.17$ \\
\hline 22 & - & 0.57 & - & $0.18 \pm 0.006$ \\
\hline 23 & - & 0.57 & - & $0.79 \pm 0.03$ \\
\hline & & & & $10.51 \pm 0.24$ \\
\hline
\end{tabular}

unperturbed and anthropogenically influenced measurements in natural ecosystems. We discuss several of the key differences between the regions for selected landcovers (for which there are measurements in multiple landcovers), along with reasons for differences, e.g. different measured fluxes, simulated soil temperature and moisture as well as other unaccounted factors. The unaccounted factors include primarily the amount of available nitrogen and the organic material and its quality, since $\mathrm{SNO}_{\mathrm{x}}$ is mainly produced in the uppermost centimeters of the soil, including the organic layer (Jambert et al., 1994; Papke and Papen, 1998; Bargsten et al., 2010).

\section{Cold savannah (10)}

For EUR compared to NAM we calculate an emission factor that is more than twice as high, although the emission fluxes are very similar with $4.40_{-2.42}^{+5.38}$ and $3.62_{-2.40}^{+7.14} \mathrm{ng} \mathrm{m}^{-2} \mathrm{~s}^{-1}$, respectively. The calculations for EUR were taken from 2 publications (10 sites) and for NAM from 3 publications (15 sites). The difference is due to the simulated soil tempera- ture, which is around $15^{\circ} \mathrm{C}$ for nearly all measurements in EUR and NAM, except for 3 measurements in EUR with measured values of $2.06,1.67$ and $6.82 \mathrm{ng} \mathrm{m}^{-2} \mathrm{~s}^{-1}$ at $1^{\circ} \mathrm{C}$ and for one with a flux of $1.9 \mathrm{ng} \mathrm{m}^{-2} \mathrm{~s}^{-1}$ at $6^{\circ} \mathrm{C}$. Thus, similar fluxes were measured in the two regions, but the simulated soil temperature differs. To yield the same emission factor for the EUR sites with the measured $\mathrm{SNO}_{\mathrm{x}}$ flux data, we would have to increase the temperature in EUR by $10 \mathrm{~K}$ in our model, which is unlikely; therefore other unaccounted factors must exist, which cause these differences.

\section{Warm savannah (11)}

Although the measured flux in SAM is higher than in AFR, we calculate higher emission factors for AFR than for SAM. This can be explained by both the soil moisture and the temperature. In AFR we have more days with a volumetric soil moisture content below $15 \%$, whereas in SAM the wet flux dominates. The mean temperatures in SAM are 27.0$29.4^{\circ} \mathrm{C}$, just slightly below $30^{\circ} \mathrm{C}$, while in AFR they are well below $30^{\circ} \mathrm{C}$ for most of the 17 measurements $\left(2\right.$ at $9.9^{\circ} \mathrm{C}$, 3 at $13-14.9^{\circ} \mathrm{C}$ and 6 at $22.3-24.3^{\circ} \mathrm{C}$ ). Therefore a higher emission factor is necessary in AFR than in SAM, which represents other controlling factors that are not yet explicitly considered in the algorithm.

\section{Warm grassland (12)}

The emission factors calculated for EUR and especially ASA are much higher than for the other three regions. In EUR the mean soil temperatures are all below $20^{\circ} \mathrm{C}$ and in ASA below $15^{\circ} \mathrm{C}$. In AFR, which also has a relatively high flux, the wet soil regime is dominant, resulting in a lower emission factor. The measured flux in NAM is low compared to the other regions, yielding a lower emission factor. Due to these reasons higher emission factors are needed in EUR and ASA.

\section{Woody savannah (13)}

The emission factors are calculated to be higher in SAM than in AFR; since soil temperature and moisture do not differ very much, this is simply due to higher emission fluxes measured in SAM than in AFR.

\section{Deciduous broadleaved forest (16)}

The calculated emission factors are higher in NAM than in EUR, mainly because the measured fluxes in NAM are higher than in EUR, and in EUR there are more wet emission periods than in NAM. 


\section{Evergreen broadleaved forest (20)}

Most of the measurements were performed in SAM, for which the calculated emission factor is nearly the same as in AFR, while a lower emission factor is calculated for ASA due to lower measured fluxes than in SAM and AFR.

\section{Agriculture (21)}

The emission factor is only calculated for wet soil conditions as proposed by YL95. NAM has a similar mean measured emission flux to ASA, but the temperature is on average higher, resulting in a higher emission factor for ASA. In AFR we also calculate a high emission factor, but only two measurements were performed in agricultural areas in Africa with a high emission flux.

\subsubsection{Global results}

The final stage of the direct surface emissions (prior to implementing the canopy reduction factor) is YL95/SL11. For the new emission factors in this simulation, we used the values listed in Tables 5 and 6 . When there were no measurements in a landcover class (IDs: 7, 9, 15, 17, 22, 23), we used the emission factor of the most similar class (see Table 1). For example, for deciduous needleleaved forest (17), we choose the same emission factor as for deciduous broadleaved forest in cold climate (16), since they are more similar than compared to evergreen needleleaved forests (Vogt et al., 1986).

In the step from LC + FIE + VSM to YL95/SL11 we find an increase of all emission factors in all landcover classes except for cold open shrubland (8), warm savannah (11) and evergreen broadleaved forest in warm climates (20), where the emissions decrease by $0.02 \mathrm{Tg}(\mathrm{N}) \mathrm{yr}^{-1}(81 \%)$, $0.58 \mathrm{Tg}(\mathrm{N}) \mathrm{yr}^{-1}(47 \%)$ and $1.94 \mathrm{Tg}(\mathrm{N}) \mathrm{yr}^{-1}(83 \%)$, respectively. On a global scale the decrease is only visible in the tropical regions (Fig. 9), where the latter two landcovers are mainly located.

The strongest increases (greater than $0.5 \mathrm{Tg}(\mathrm{N}) \mathrm{yr}^{-1}$ ) in the annual global flux were simulated for woody savannah (13), evergreen needleleaved forest (18) and cropland (21) with $1.78(352 \%), 0.73(4796 \%)$ and $0.85 \mathrm{Tg}(\mathrm{N}) \mathrm{yr}^{-1}$ $(35 \%)$ increases, respectively. Globally this leads to an increase of $2.43 \mathrm{Tg}(\mathrm{N}) \mathrm{yr}^{-1}(24 \%)$ compared to the $\mathrm{LC}+\mathrm{FIE}+\mathrm{VSM}$ simulation.

Since we increase the emissions from agricultural land cover classes (21-23) from $3.13 \mathrm{Tg}(\mathrm{N}) \mathrm{yr}^{-1}$ in the LC + FIE simulation to $4.22 \operatorname{Tg}(\mathrm{N})$, we further depart from the values of Stehfest and Bouwman (2006) and Bouwman et al. (2002) (1.8 and $1.6 \mathrm{Tg}(\mathrm{N}) \mathrm{yr}^{-1}$, respectively), but are still within their $95 \%$ confidence interval. We also calculated the emission factors per crop type separately (Fig. 10). Although there are not enough observations at present to implement such a distinction reliably into the algorithm, this may be interesting to pursue in future research, and we lay the
Table 6. The adopted (YL95/SL11) emission factors (arithmetic mean) and associated soil biogenic NO emissions.

\begin{tabular}{rrccc}
\hline \multicolumn{5}{c}{ Emission factors } \\
ID & \multicolumn{1}{c}{$\mathrm{N}$} & wet & dry & {$\left[\frac{\mathrm{Tg}(\mathrm{N})}{\text { year }}\right]$} \\
\hline 0 & 0 & 0 & 0 & 0 \\
1 & 0 & 0 & 0 & 0 \\
2 & 0 & 0 & 0 & 0 \\
3 & 0 & 0 & 0 & 0 \\
4 & 0 & 0 & 0 & 0 \\
5 & $31(3)$ & $0.06 \pm 0.01$ & $0.45 \pm 0.10$ & $0.21 \pm 0.005$ \\
6 & $220(20)$ & $0.21 \pm 0.24$ & $1.55 \pm 1.75$ & 0.04 \\
7 & - & 0.21 & 1.55 & $0.78 \pm 0.03$ \\
8 & $11(1)$ & $0.01 \pm 0.00$ & $0.05 \pm 0.01$ & 0.005 \\
9 & - & 1.05 & 7.75 & $0.04 \pm 0.002$ \\
10 & $275(25)$ & $1.05 \pm 1.37$ & $7.75 \pm 10.12$ & $0.40 \pm 0.02$ \\
11 & $308(28)$ & $0.97 \pm 1.75$ & $7.15 \pm 12.86$ & $2.20 \pm 0.04$ \\
12 & $1135(105)$ & $1.78 \pm 4.34$ & $13.11 \pm 31.98$ & $5.0 \pm 0.1$ \\
13 & $99(9)$ & $0.74 \pm 0.50$ & $6.26 \pm 4.24$ & $2.44 \pm 0.04$ \\
14 & $44(4)$ & $0.14 \pm 0.24$ & $1.01 \pm 1.80$ & $0.06 \pm 0.002$ \\
15 & $10(1)^{*}$ & 0.95 & 6.33 & $0.44 \pm 0.01$ \\
16 & $227(22)$ & $0.95 \pm 1.48$ & $6.33 \pm 9.84$ & $0.31 \pm 0.01$ \\
17 & - & 0.95 & 6.33 & 0.006 \\
18 & $800(74)$ & $4.60 \pm 4.34$ & $33.70 \pm 31.84$ & $2.46 \pm 0.09$ \\
19 & $77(7)$ & $0.13 \pm 0.14$ & $0.99 \pm 1.06$ & 0.03 \\
20 & $612(57)$ & $1.14 \pm 2.31$ & $5.33 \pm 9.63$ & $1.15 \pm 0.02$ \\
21 & $2361(219)$ & $3.13 \pm 7.84$ & - & $13.58 \pm 0.32$ \\
22 & - & 3.13 & - & $0.69 \pm 0.01$ \\
23 & - & 3.13 & - & $3.22 \pm 0.1$ \\
\hline sum & & & & $33.12 \pm 0.64$ \\
\hline & & & &
\end{tabular}

* One flux measurement was 0 , therefore emission factors $f$ landcover 16 were assumed.

groundwork for that here. These emission factors calculated per crop type span over more than an order of magnitude, with the lowest one in rice fields; here in particular we see the need for additional measurements, since there were only two measurements conducted in rice fields.

The new total $\mathrm{SNO}_{\mathrm{x}}$ flux is now $10.51 \mathrm{Tg}(\mathrm{N}) \mathrm{yr}^{-1}$ without the reduction in the "rice-producing areas", and $9.4 \mathrm{Tg}(\mathrm{N}) \mathrm{yr}^{-1}$ when the reduction is included.

\subsection{Canopy reduction factor (CRF)}

We also use an updated map of the monthly mean leaf area index (LAI), published by Deng et al. (2006), to calculate the canopy reduction factor (CRF), which is relevant for the comparision with satellite-based estimates in the next section. The data of Deng et al. (2006) is available starting in 1998 , so that we could not use the appropriate annual cycle of LAI for the full simulation period. Instead, we used the average of each month for the years 1999, 2002, 2003 and 2005; these were chosen because other years had unrealistically high values in the Sahel region or atificial straight lines in the data. On an annual average the CRF does not change much 

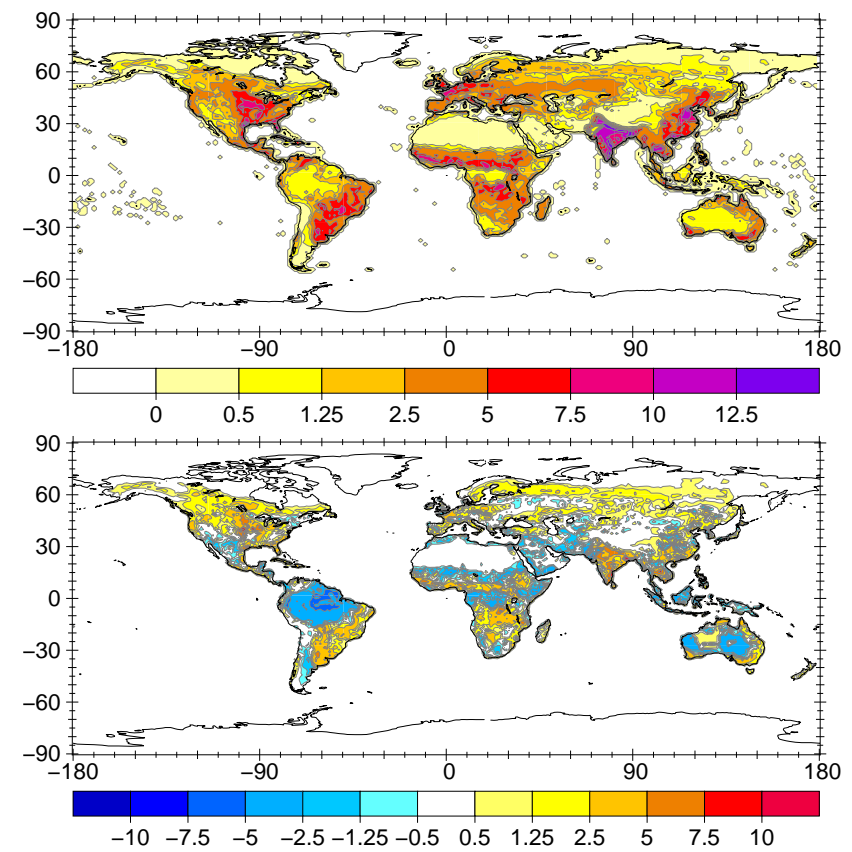

Fig. 9. Averaged $\mathrm{SNO}_{\mathrm{x}}$ flux in the whole simulation period (in $n \mathrm{n} \mathrm{m}^{-2} \mathrm{~s}^{-1}$ ) for the YL95/SL11 simulation (upper panel) and the change compared to the YL95EMAC simulation (lower panel).

from YL95EMAC $(\mathrm{CRF}=0.74)$ through $\mathrm{LC}(\mathrm{CRF}=0.77)$, $\mathrm{LC}+\mathrm{F}$ IE $(0.76)$ and $\mathrm{LC}+\mathrm{FIE}+\mathrm{VSM}(\mathrm{CRF}=0.75)$. However, since in the YL95/SL11 simulation the emissions in tropical evergreen forests decrease and the emissions from deserts increase, the global averaged CRF increases to 0.82 , yielding in an even greater net flux to the atmosphere.

\section{Comparison to satellite-derived emission estimates}

Since we used all available measurements to provide the best statistics for adjusting our emission factors, there are no independent in situ measurements left to evaluate our new implementation of the $\mathrm{SNO}_{\mathrm{x}}$ algorithm by Yienger and Levy (1995). Therefore we compare our YL95/SL11 above canopy flux with the a posteriori $\mathrm{SNO}_{\mathrm{x}}$ fluxes of Jaeglé et al. (2005) for the year 2000, which are partly constrained by independent satellite-based measurements. Jaeglé et al. (2005) also use the algorithm by Yienger and Levy (1995) in their a priori simulations, but implemented in another global climate model. Jaeglé et al. (2005) use the $\mathrm{NO}_{2}$ column derived from the GOME satellite instrument (Burrows et al., 1999) in an inverse modelling framework based on a global chemistrtransport model, the GEOS-Chem model (Bey et al., 2001). $\mathrm{NO}_{\mathrm{x}}$ emissions from fossil fuel combustion are distinguished from other sources in a first step. In a second step they further partition the remaining sources in biomass burning events and soils, by using the firecounts of other satellite instruments (Langaans, 1993; Eva and Lambin, 1998; Giglio et al., 2003).

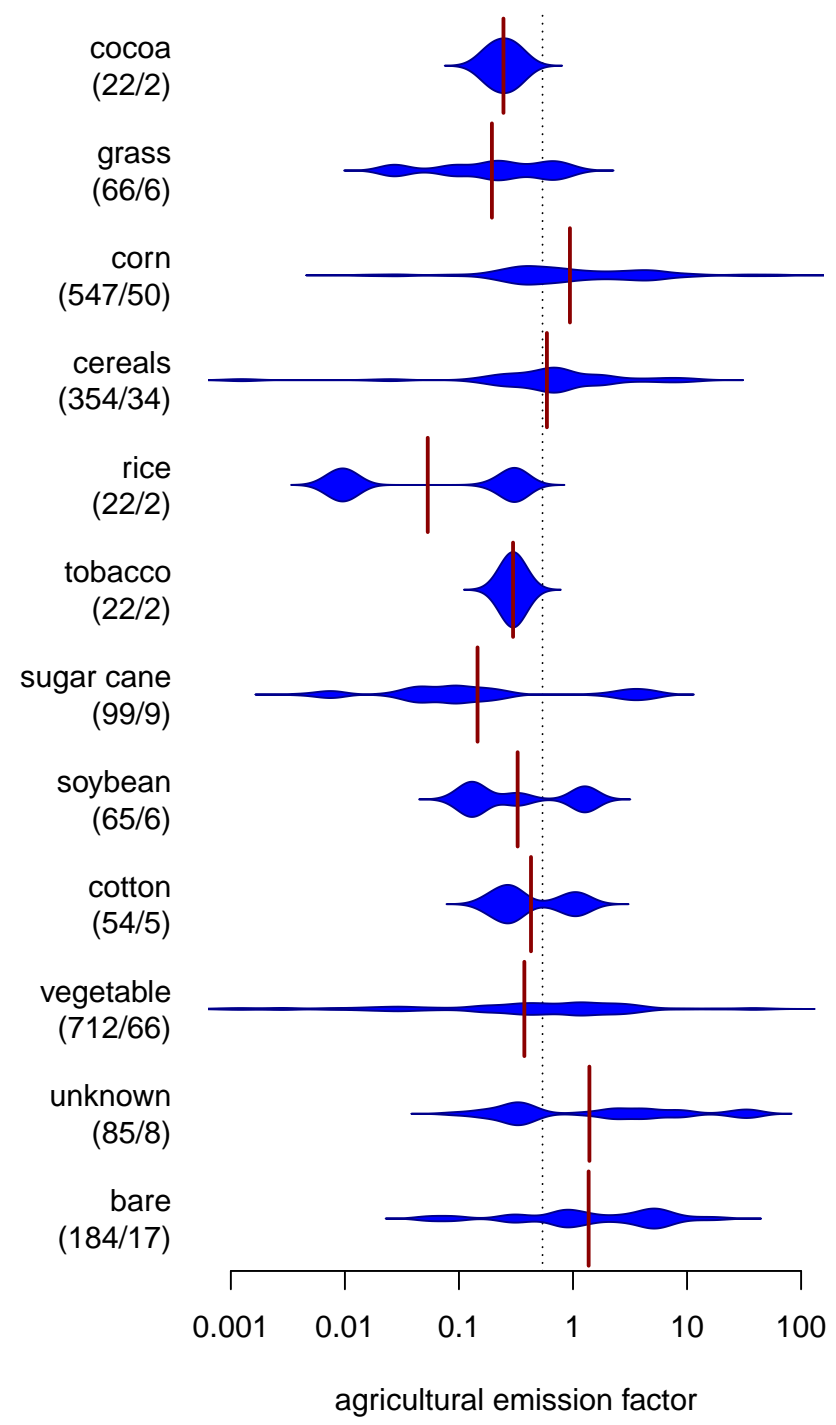

Fig. 10. Distribution of calculated wet emissions factors for different crop types in the landcover "agriculture" with the number of calculated emission factors and number of measurements per crop class in brackets.

The annual global $\mathrm{SNO}_{\mathrm{x}}$ of YL95/SL11 $\left(8.61 \mathrm{Tg}(\mathrm{N}) \mathrm{yr}^{-1}\right)$ differs by $3 \%$ from their annual $\mathrm{SNO}_{\mathrm{x}}$ of $8.84 \mathrm{Tg}(\mathrm{N}) \mathrm{yr}^{-1}$ and is much closer to Jaeglé et al. (2005) than the $6.88 \mathrm{Tg}(\mathrm{N}) \mathrm{yr}^{-1}$ above canopy flux in YL95EMAC and 5.5 $\mathrm{Tg}(\mathrm{N}) \mathrm{yr}^{-1}$ in YL95. By comparing Fig. 11a with Fig. 9a we see that many of the features of our simulated bottom-up distribution are similar to their top-down study (e.g. tropical rainforest), though there are notable differences (e.g. forested areas at mid- and high latitudes or arid regions), which are highlighted in Fig. 11b. There are several reasons for the differences, as discussed below. 

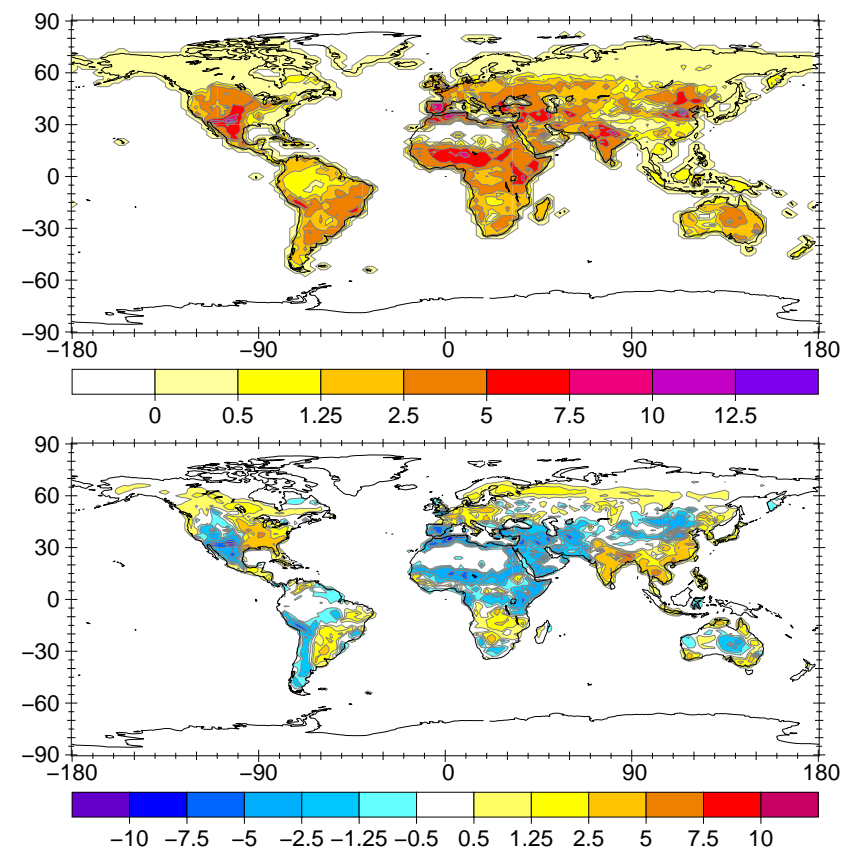

Fig. 11. Averaged $\mathrm{SNO}_{\mathrm{x}}$ flux for the year 2000 of the Jaeglé et al. (2005) (J05) inverse modeling study (in $\mathrm{ng} \mathrm{m}^{-2} \mathrm{~s}^{-1}$ ) (upper panel) and the difference between the YL95/SL11 year 2000 simulation and the J05 results (YL95/SL11 - J05) (lower panel).

We calculate higher emissions in large areas of Europe except Spain, where Jaeglé et al. (2005) compute much higher emissions. Our simulated flux is also higher in other regions, as can be seen in Fig. 11. However, there are also regions where our simulated flux is lower. Over the tropical rainforest, where $\mathrm{SNO}_{\mathrm{x}}$ has the strongest impact on chemical processes in the atmosphere (Steinkamp et al., 2009) the emissions in YL95/SL11 are similar to Jaeglé et al. (2005). It is worth noting that this reduction in the tropical emissions compared to YL95EMAC (see Fig. 12 for the difference between Jaeglé et al. (2005) and YL95EMAC) will reduce the influence of $\mathrm{SNO}_{\mathrm{x}}$ on global ozone chemistry, while on the other hand the general increase in $\mathrm{SNO}_{\mathrm{x}}$ will in turn increase the influence.

The reduced flux over arid regions of the Middle East to Pakistan, the Sahel region and Australia may be explained by unrealistic landcover classes in our classification, the simulated soil moisture state (see Sect. 3.5) or due to the constraints provided by the satellite $\mathrm{NO}_{2}$ columns. For example along the northern African Mediterranean coast, agricultural areas in our landcover map seem to be much smaller compared to Pongratz et al. (2008). This alone may not be enough to explain the higher fluxes from semi-arid regions, including the southwestern USA, Mexico and the Sahel region, suggesting that our model still underestimates fluxes in (semi-)arid regions compared to Jaeglé et al. (2005).

In the mountainous regions along the American west coast we also get lower emissions and we contend that it seems

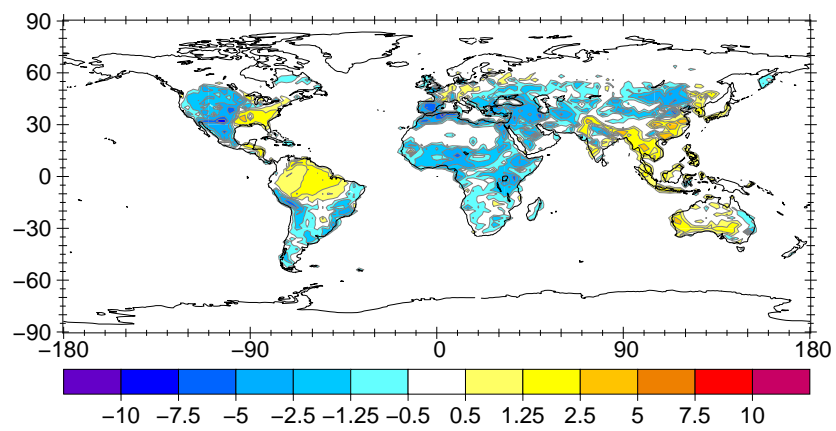

Fig. 12. Difference between YL95EMAC and Jaeglé et al. (2005) (YL95EMAC - J05) (in $\mathrm{ng} \mathrm{m}^{-2} \mathrm{~s}^{-1}$ ) for the year 2000.

more sensible to have lower emissions from such regions of high altitudes. Furthermore, the higher emissions in our simulation from agriculture in the central and eastern parts of North America are reasonable compared to independent land usage distributions (Pongratz et al., 2008; Sterling and Ducharne, 2008). In the tropical region of South America our results agree well and are a clear improvement over YL95EMAC. But over tropical Africa our simulated $\mathrm{SNO}_{\mathrm{x}}$ is still lower than the results by Jaeglé et al. (2005).

There have also been a few regional applications of the top-down approach to eastern China using the GOME (Wang et al., 2007) and OMI satellite instruments (Zhao and Wang, 2009). These two studies find an increase by $260 \%$ and $240 \%$ for $\mathrm{SNO}_{\mathrm{x}}$ compared to their a priori $\mathrm{SNO}_{\mathrm{x}}$, respectively. Their a priori estimate is comparable to our $\mathrm{SNO}_{\mathrm{x}}$ in the geometric mean calculation YL95/SL11 with reduced emissions in "rice-producing regions" (Table 7). The closest value to their a posteriori annual global $\mathrm{SNO}_{\mathrm{x}}$ is our emission using the arithmetic mean calculation without reduced in "rice-producing regions", but this is even higher than their estimate. Other authors do not find such a strong relative increase in eastern China (Müller and Stavrakou, 2005; Stavrakou et al., 2008), however this is partly because Stavrakou et al. (2008) already scaled their global a priori emissions to a global value of $8 \mathrm{Tg}(\mathrm{N}) \mathrm{yr}^{-1}$. The a posteriori estimate of Müller and Stavrakou (2005) and Stavrakou et al. (2008) is $10-12.1 \mathrm{Tg}(\mathrm{N}) \mathrm{yr}^{-1}$, which is slightly larger than our best estimate using the arithmetic mean calculation.

\section{Discussion}

As expected, the mean value of the mesurements are in good agreement with the ones simulated with the adjusted $\mathrm{SNO}_{\mathrm{x}}$ fluxes in YL95/SL11 (Fig. 13). Small deviations occur, because we used exactly the corresponding start and end day of the measurements. We still have a "cloudy" distribution around the 1:1 line (Fig. 13), which can be expected for this kind of statistical model, since there are several unaccounted parameters which affect each landcover class, like 

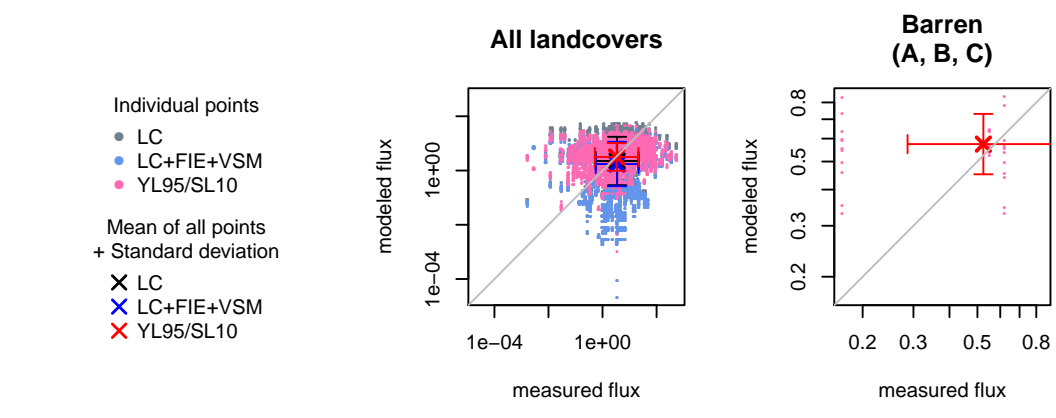

Closed shrubland

Open shrubland

(D, E)
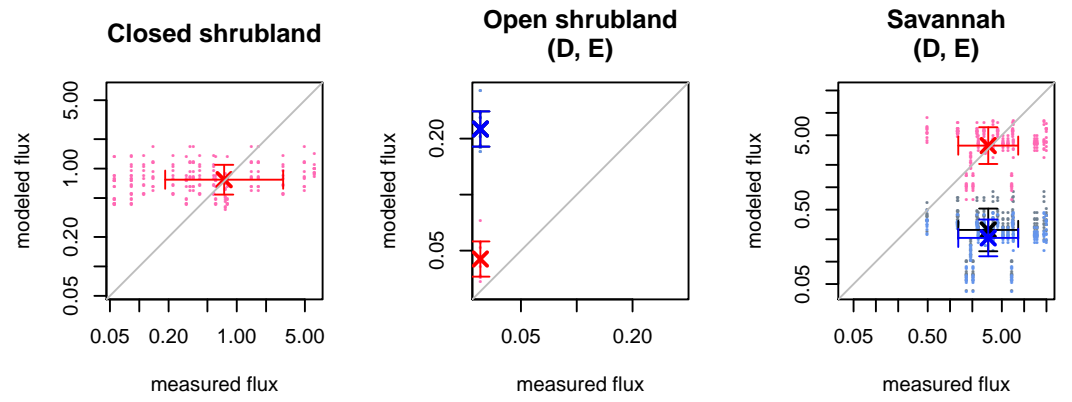

Savannah

(A, B, C)
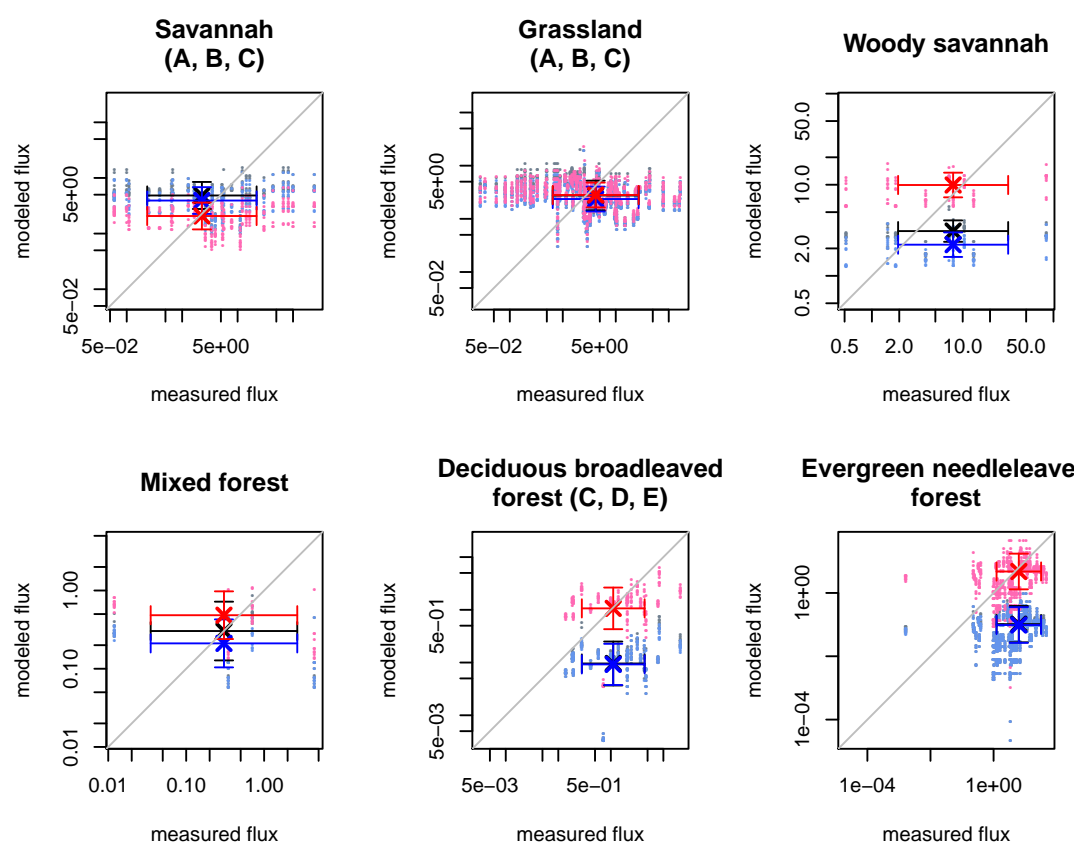

\section{Evergreen needleleaved}
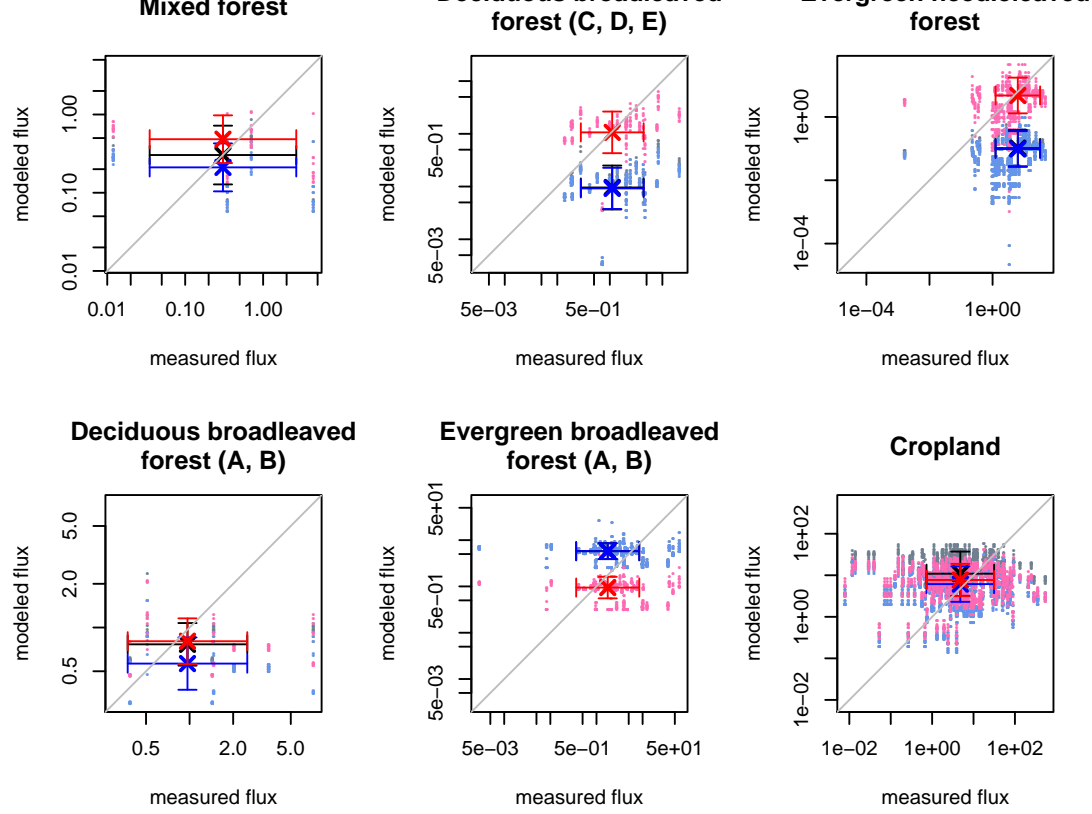

Fig. 13. Scatterplots of $\mathrm{SNO}_{\mathrm{x}}$ measurements versus model results for the YL95/SL11 simulations. 

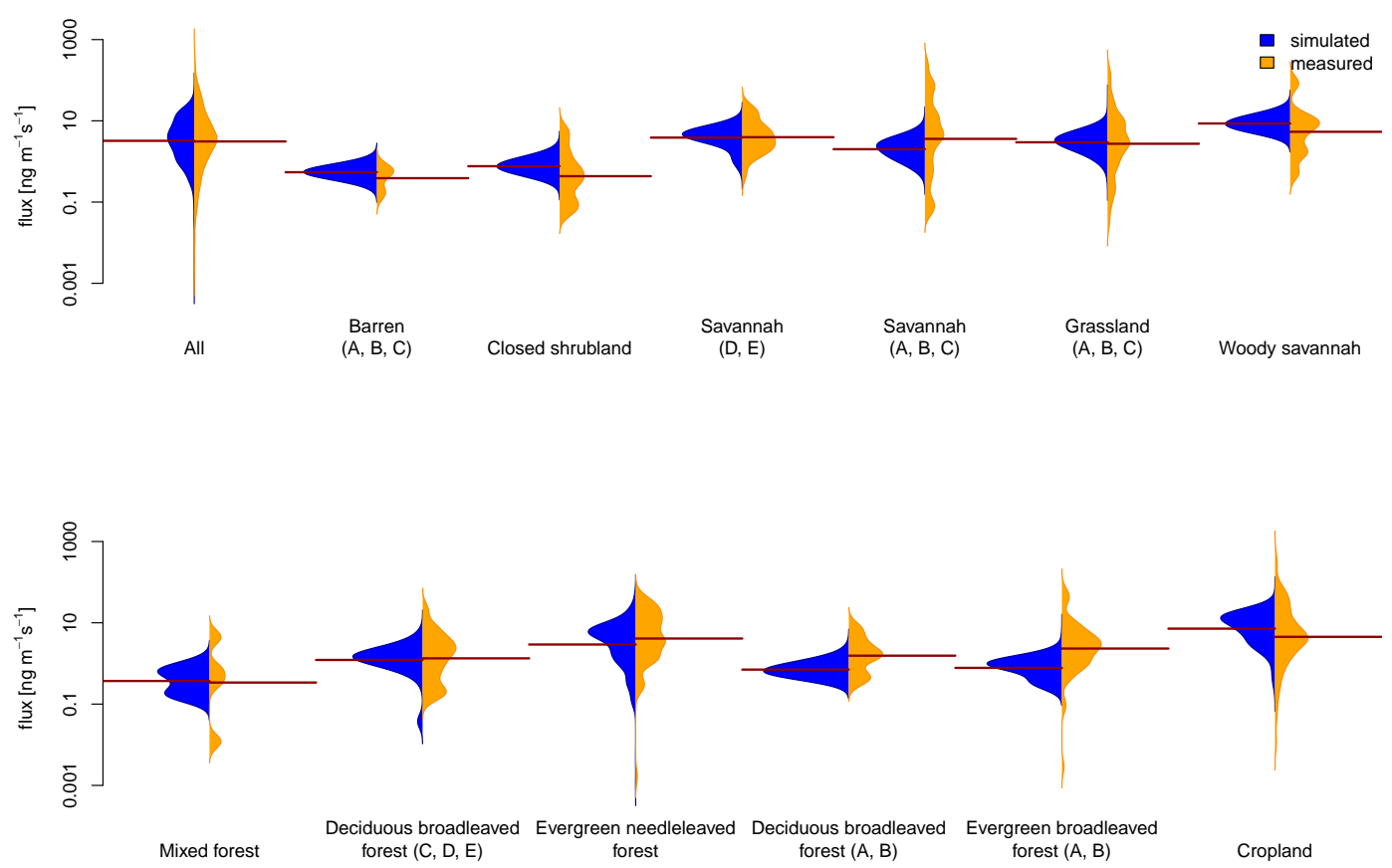

Fig. 14. Density function plot of $\mathrm{SNO}_{\mathrm{x}}$ measurements (orange, right of center line) versus model output (blue, left of center line) for the YL95/SL11 simulation using the program by Kampstra (2008).

Table 7. Comparison of new $\mathrm{SNO}_{\mathrm{x}}$ to a top-down study in eastern China.

\begin{tabular}{|c|c|c|c|c|c|}
\hline & DJF & MAM & JJA & SON & year \\
\hline \multicolumn{6}{|c|}{ Wang et al. (2007) } \\
\hline a priori & 0.016 & 0.06 & 0.12 & 0.04 & 0.236 \\
\hline a posteriori & 0.04 & 0.21 & 0.36 & 0.24 & 0.85 \\
\hline \multicolumn{6}{|l|}{ This stuy } \\
\hline geom. mean ${ }^{\mathrm{a}}$ & 0.01 & 0.05 & 0.08 & 0.03 & 0.18 \\
\hline geom. mean ${ }^{b}$ & 0.03 & 0.08 & 0.14 & 0.06 & 0.31 \\
\hline arithm. mean ${ }^{\mathrm{a}}$ & 0.02 & 0.12 & 0.22 & 0.10 & 0.47 \\
\hline arithm. mean ${ }^{\mathrm{b}}$ & 0.07 & 0.26 & 0.42 & 0.22 & 0.97 \\
\hline
\end{tabular}

a reduced emissions in "rice-growing regions".

$\mathrm{b}$ without reduced emissions in "rice-growing regions".

the heterogenity in soil parameters or the adaptation of NO producing microorganisms to different habitats. This is reflected in the logarithmic density distribution functions of the measurements (Fig. 14), which have much larger tails compared to the simulated fluxes.

An analysis similar to the one performed in Sect. 3.6.1 can be performed by classifying the data by the duration of the experimental period. In particular, there were a few landcover classes $(5,11,14,19)$ with short term measurements (less than 3 months). One might expect that short term measurements will often have been performed specifically to measure special events, like rain induced pulsing or fertilizer induced emission, so that the limitation to long term measurements in our analyses could cause the calculated emission factor to decrease. However, we do not find this to be the case when we leave out these classes. In general, no connection is evident between the length of the measurement and the calculated new emission factors.

The reduction of $\mathrm{SNO}_{\mathrm{x}}$ in "rice-producing areas" that was implemented by Yienger and Levy (1995) is highly uncertain, and there are several pieces of evidence for and against it. Their original implementation was based on only one publication. Some more recent publications also support this conclusion, for instance, Zheng et al. (2003) report that periodic flooding during rice production decreases the $\mathrm{SNO}_{\mathrm{x}}$ even during non-flooded periods, and in a field campaign Fang and $\mathrm{Mu}$ (2009) found that the flux from rice fields is lower compared to other vegetable fields. The emission factor from rice-producing regions is also found to be lower in our analyses, but this is based on only two measurements in our dataset, and thus we agree with the earlier conclusion of the FAO and IFA (2001) that there are still not enough measurements available to draw any solid conclusions on this effect. Although we doubled the number of landcover classes there is still a large variability within individual classes, which is evident from the comparison of the continental/regional differences within one landcover class. Furthermore, in the probability density distributions depicted in Fig. 14, the measured fluxes show a much broader distribution and much stronger bi- to multimodal characteristics 
compared to our simulated values within each landcover class. Other important limitations of our improved algorithm are:

- The gridbox size of more than $100 \times 100 \mathrm{~km}$ is too large to accurately reproduce the measured fluxes; this is a persistent problem in global models, and even if we were to decrease the cell size by a few orders of magnitude, it would not be sufficent to capture the heterogenity in real soils.

- Instead of having only two soil moisture regimes, in reality one would expect a continous mathematical relationship, such as that proposed and confirmed in laboratory measurements by Meixner and Yang (2006).

- Even if the algorithm itself were to be perfect, the use of simulated soil moisture and soil temperature will lead to errors, since these are also not perfectly representative of reality.

Ideally the optimization we performed here would need to be repeated for each resolution at which the model is running, otherwise $\mathrm{SNO}_{\mathrm{x}}$ will be underestimated at coarser resolutions and overestimated at finer resolutions (Fig. 6). One possibility to improve the total annual flux at lower resolutions would be to simply increase the emissions rate by a factor equal to the relative difference in the resolutions. However, this would still not be perfect, due to non-linearities in the simulations; for example, the areal fraction of soils defined as wet increases slightly at finer resolution, which in turn causes $\mathrm{SNO}_{\mathrm{x}}$ to increase at higher temperatures.

\section{Conclusions}

We have made significant improvements to the soil NO emission algorithm developed by Yienger and Levy (1995) using a much larger set of in situ measurements, along with several other recent advances such as more detailed land cover classifications. The total global above-canopy flux increases by $1.73 \mathrm{Tg} \mathrm{yr}^{-1}$ and we obtain a significant difference in the geographical distribution of $\mathrm{SNO}_{\mathrm{x}}$. Despite this overall increase in $\mathrm{SNO}_{\mathrm{x}}$, there is a reduction of $\mathrm{SNO}_{\mathrm{x}}$ in tropical regions compared to the previous implementation in EMAC, which will in turn reduce the relative influence on atmospheric chemistry (in particular $\mathrm{O}_{3}$ and $\mathrm{OH}$, and the tropospheric oxidizing efficiency), as discussed in Steinkamp et al. (2009).

As long as there is no mechanistically based algorithm to calculate $\mathrm{SNO}_{\mathrm{x}}$, which will be difficult to develop for global models due to the heterogeneity of soils, vegetation and microorganisms, a valuable approach will be to continue adjusting the calculation of $\mathrm{SNO}_{\mathrm{x}}$ as we have done with new measurements and other advances in the field. Since the algorithm by Yienger and Levy (1995) is the most-widely applied method to calculate $\mathrm{SNO}_{\mathrm{x}}$ in AC-GCMs, the method we presented here can also be easily applied in other models, either directly applying our new fitted parameters, or attaining greater internal model consistency by applying the same fitting technique with the observations. Finally, with a growing amount of measurements of $\mathrm{SNO}_{\mathrm{x}}$ accompanied with the measurement of other relevant factors, it should eventually be possible to incorporate other factors in the parameterization, resulting in an improved agreement, in particular reducing the scatter in the comparison of modeled and observed $\mathrm{SNO}_{\mathrm{x}}$.

\section{Supplementary material related to this article is available online at: http://www.atmos-chem-phys.net/11/6063/2011/ acp-11-6063-2011-supplement.pdf.}

Acknowledgements. We would like to thank Stefan Hagemann from the MPI for Meteorology in Hamburg for the calculation of the volumetric soil moisture, Jos Lelieveld for the initial suggestions and very fruitful discussions, Wolgang Wilcke for his constructive comments, Lyatt Jaeglé for providing her a posteriori top-down satellite data, and the EMAC developers and users for their support, especially L. N. Ganzeveld, P. Jöckel, A. Kerkweg and H. Tost. Jörg Steinkamp apreciates the financial support by the International Max Planck Research School (IMPRS) for atmosperic chemistry and physics as well as additional support from the Biodiversity and Climate Research Centre (BiK-F), Frankfurt am Main, which is part of the research funding programme "LOEWE - Landes-Offensive zur Entwicklung Wissenschaftlich-ökonomischer Exzellenz" of the Ministry of Higher Education, Research and Arts, State of Hesse, Germany. We appreciate the detailed and constructive comments of our reviewers, which helped a lot to improve the quality of this article.

The service charges for this open access publication have been covered by the Max Planck Society.

Edited by: J. Rinne

\section{References}

Bargsten, A., Falge, E., Pritsch, K., E., Huwe, B., and Meixner, F. X.: Laboratory measurements of nitric oxide release from forest soil with a thick organic layer under different understory types, Biogeosciences, 7, 1425-1441, doi:10.5194/bg-7-14252010, 2010.

Bertram, T. H., Heckel, A., Richter, A., Burrows, J. P., and Cohen, R. C.: Satellite measurements of daily variations in soil $\mathrm{NO}_{\mathrm{x}}$ emissions, Geophys. Res. Lett., 32, L24812, doi:10.1029/2005GL024640, 2005.

Bey, I., Jacob, D., Yantosca, R., Logan, J., Field, B., Fiore, A., Li, Q., Liu, H., Mickley, L., and Schultz, M. G.: Global modeling of tropospheric chemistry with assimilated meteorology: Model description and evaluation, J. Geophys. Res., 106, 23073-23095, doi:10.1029/2001JD000807, 2001.

Bouwman, A. F., Boumans, L. J. M., and Batjes, N. H.: Modeling global annual $\mathrm{N}_{2} \mathrm{O}$ and $\mathrm{NO}$ emissions from 
fertilized fields, Global Biogeochem. Cy., 16, 1080, doi:10.1029/2001GB001812, 2002.

Burrows, J. P., Weber, M., Buchwitz, M., Rozanov, V., LadstätterWeißenmayer, A., Richter, A., DeBeek, R., Hoogen, R., Bramstedt, K., Eichmann, K.-U., Eisinger, M., and Perner, D.: The Global Ozone Monitoring Experiment (GOME): Mission concept and first scientific results, J. Atmos. Sci., 56, 151-175, doi:10.1175/1520-0469(1999)056;0151:TGOMEG;2.0.CO;2, 1999.

Chameides, W. L., Fehsenfeld, F., Rodgers, M. O., Cardelino, C., Martinez, J., Parrish, D., Lonneman, W., Lawson, D. R., Rasmussen, R. A., Zimmermann, P., Greenberg, J., Middleton, P., and Wang, T.: Ozone precursor relationships in the ambient atmosphere, J. Geophys. Res., 97, 6037-6055, 1992.

Davidson, E. A.: Pulses of nitric oxide and nitrous oxide flux following wetting of dry soil: an assessment of probable sources and importance relative to annual fluxes, Ecol. Bull., 42, 149$155,1992$.

Davidson, E. A. and Kingerlee, W.: A global inventory of nitric oxide emissions from soils, Nutr. Cycl. Agroecosys., 48, 37-50, 1997.

Davidson, E. A., Vitousek, P. M., Matson, P. A., Riley, R., GarcíaMéndez, G., and Maass, J. M.: Soil emissions of nitric oxide in a seasonally dry tropical forest in México, J. Geophys. Res., 96, 15439-15445, 1991.

Delon, C., Reeves, C. E., Stewart, D. J., Serça, D., Dupont, R., Mari, C., Chaboureau, J.-P., and Tulet, P.: Biogenic nitrogen oxide emissions from soils - impact on $\mathrm{NO}_{\mathrm{x}}$ and ozone over West Africa during AMMA (African Monsoon Multidisciplinary Experiment): modelling study, Atmos. Chem. Phys., 8, 2351-2363, doi:10.5194/acp-8-2351-2008, 2008.

Deng, F., Chen, J. M., Plummer, S., Chen, M., and Pisek, J.: Algorithm for global Leaf Area Index retrieval using satellite imagery, IEEE T. Geosci. Remote, 44, 2219-2229, 2006.

Denman, K. L., Brasseur, G., Chidthaisong, A., Ciais, P., Cox, P. M., Dickinson, R. E., Hauglustaine, D., Heinze, C., Holland, E., Jacob, D., Lohmann, U., Ramachandran, S., da Silva Dias, P. L., Wofsy, S. C., and Zhang, X.: Couplings Between Changes in the Climate System and Biogeochemistry, in: Climate Change 2007: The Physical Science Basis. Contribution of Working Group I to the Fourth Assessment Report of the Intergovernmental Panel on Climate Change, edited by: Solomon, S., Qin, D., Manning, M., Chen, Z., Marquis, M., Averyt, K. B., Tignor, M., and Miller, H. L., pp. 499-587, Cambridge University Press, Cambridge, United Kingdom and New York, NY, USA, 2007.

Drusch, M., Scipal, K., de Rosnay, P., Balsamo, G., Andersson, E., Bougeault, P., and Viterbo, P.: Towards a Kalman Filter based soil moisture analysis system for the operational ECMWF Integrated Forecast System, Geophys. Res. Lett., 36, L10401, doi:10.1029/2009GL037716, 2009.

Eva, H. and Lambin, E. F.: Remote sensing of biomass burning in tropical regions: Sampling issues and multisensor approach, Remote Sens. Environ., 64, 292-315, 1998.

Fang, S. and $\mathrm{Mu}$, Y.: NOx fluxes from several typical agricultural fields during summer-autumn in the Yangtse Delta, China, Atmos. Environ., 43, 2665-2671, doi:10.1016/j.atmosenv.2009.02.027, 2009.

FAO and IFA: Global estimates of gaseous emissions of $\mathrm{NH}_{3}, \mathrm{NO}$ and $\mathrm{N}_{2} \mathrm{O}$ from agricultural land, FAO and IFA, Rome, Italy,
2001.

Friedl, M. A., McIver, D. K., Hodges, J. C. F., Zhang, X. Y., Muchoney, D., Strahler, A. H., Woodcock, C. E., Gopal, S., Schneider, A., Cooper, A., Baccini, A., Gao, F., and Schaaf, C.: Global land cover mapping from MODIS: algorithms and early results, Remote Sens. Environ., 83, 287-302, 2006.

Galbally, I. E., Freney, J. R., Muirhead, W. A., Simpson, J. R., Trevitt, A. C. F., and Chalk, P. M.: Emission of nitrogen oxides $\left(\mathrm{NO}_{\mathrm{X}}\right)$ from a flooded soil fertilized with urea: relation to other nitrogen loss processes, J. Atmos. Chem., 5, 343-365, 1987.

Ganzeveld, L. N., Lelieveld, J., Dentener, F. J., Krol, M. C., Bouwman, A. F., and Roelofs, G.-J.: Global soil-biogenic $\mathrm{NO}_{\mathrm{x}}$ emissions and the role of canopy processes, J. Geophys. Res., 107, 4321, doi:10.1029/2001JD001289, 2002.

Ganzeveld, L. N., van Aardenne, J. A., Butler, T. M., Lawrence, M. G., Metzger, S. M., Stier, P., Zimmermann, P., and Lelieveld, J.: Technical Note: Anthropogenic and natural offline emissions and the online EMissions and dry DEPosition submodel EMDEP of the Modular Earth Submodel system (MESSy), Atmos. Chem. Phys. Discuss., 6, 5457-5483, doi:10.5194/acpd-6-5457-2006, 2006.

Garcia-Montiel, D. C., Steudler, P. A., Piccolo, M., Neill, C., Melillo, J., and Cerri, C. C.: Nitrogen oxide emissions following wetting of dry soils in forest and pastures in Rondônia, Brazil, Biogeochemistry, 64, 319-336, 2003.

Giglio, L., Kendall, J. D., and Mack, R.: A multi-year active fire dataset for the tropics derived from the TRMM VIRS, Int. J. Remote Sens., 24, 4505-4525, doi:10.1080/0143116031000070283, 2003.

Hauglustaine, D. A., Hourdin, F., Jourdain, L., Filiberti, M.A., Walters, S., Lamarque, J.-F., and Holland, E. A.: Interactive chemistry in the Laboratoire de Mét 'eorologie Dynamique general circulation model: Description and background tropospheric chemistry evaluation, J. Geophys. Res., 109, D04341, doi:10.1029/2003JD003957, 2004.

Horowitz, L. W., Walters, S., Mauzerall, D. L., Emmons, L. K., Rasch, P. J., Granier, C., Tie, X., Lamarque, J.-F., Schultz, M. G., Tyndall, G. S., Orlando, J. J., and Brasseur, G. P.: A global simulation of tropospheric ozone and related tracers: Description and evaluation of MOZART, version 2, J. Geophys. Res., 108, 4784, doi:10.1029/2002JD002853, 2003.

Jacob, D. J. and Bakwin, P. S.: Cycling of $\mathrm{NO}_{\mathrm{x}}$ in tropical forest canopies, in: Microbial production and consumption of greenhouse gases: methane, nitrogen oxides, and halomethanes, edited by: Rogers, J. E. and Whitman, W. B., pp. 237-254, American Society for Microbiology, Washington, D. C., USA, 1991.

Jaeglé, L., Steinberger, L., Martin, R. V., and Chance, K.: Global partitioning of $\mathrm{NO}_{\mathrm{x}}$ sources using satellite observations: relative roles of fossil fuel combustion, biomass burning and soil emissions, Faraday Discuss., 130, 407-423, 2005.

Jambert, C., Delmas, R. A., Labroue, L., and Chassin, P.: Nitrogen compound emissions from fertilized soils in a maize field pine tree forest agrosystem in the southwest of France, J. Geophys. Res., 99, 16523-16530, 1994.

Jöckel, P., Tost, H., Pozzer, A., Brühl, C., Buchholz, J., Ganzeveld, L., Hoor, P., Kerkweg, A., Lawrence, M. G., Sander, R., Steil, B., Stiller, G., Tanarhte, M., Taraborrelli, D., van Aardenne, J., and Lelieveld, J.: The atmospheric chemistry general circulation model ECHAM5/MESSy 1: consistent simulation of ozone from 
the surface to the mesosphere, Atmos. Chem. Phys., 6, 50675104, doi:10.5194/acp-6-5067-2006, 2006.

Ju, X., Liu, X., Zhang, F., and Roelcke, M.: Nitrogen fertilization, soil nitrate accumulation and policy recommendations in several agricultural regions of China, Ambio, 33, 300-305, 2004.

Kampstra, P.: Beanplot: A boxplot altenative for visual comparison of distributions, J. Stat. Softw., 28, 1-9, 2008.

Kerkweg, A., Sander, R., Tost, H., and Jöckel, P.: Technical note: Implementation of prescribed (OFFLEM), calculated (ONLEM), and pseudo-emissions (TNUDGE) of chemical species in the Modular Earth Submodel System (MESSy), Atmos. Chem. Phys., 6, 3603-3609, doi:10.5194/acp-6-3603-2006, 2006.

Kottek, M., Grieser, J., Beck, C., Rudolf, B., and Rubel, F.: World map of the Köppen-Geiger climate classification updated, Meteorol. Z., 15, 259-263, 2006.

Langaans, S.: Diurnal cycle in savanna fires, Nature, 363, p. 120, 1993.

Lawrence, M. G., Crutzen, P. J., Rasch, P. J., Eaton, B. E., and Mahowald, N. M.: A model for studies of tropospheric photochemistry: Description, global distributions, and evaluation, J. Geophys. Res., 104, 26245-26277, 1999.

Martin, R. V., Jacob, D. J., Chance, K., Kurosu, T. P., Palmer, P. I., and Evans, M. J.: Global inventory of nitrogen oxide emissions constrained by space-based observations of $\mathrm{NO}_{2}$ columns, J. Geophys. Res., 108, 4537, doi:10.1029/2003JD003453, 2003.

Martin, R. V., Sioris, C. E., Chance, K., Ryerson, T. B., Bertram, T. H., Wooldridge, P. J., Cohen, R. C., Neuman, J. A., Swanson, A., and Flocke, F. M.: Evaluation of space-based constraints on global nitrogen oxide emissions with regional aircraft measurements over and downwind of eastern North America, J. Geophys. Res., 111, D15308, doi10.1029/2005JD006680, 2006.

Meixner, F. X. and Yang, W. X.: Biogenic emissions of nitric oxide and nitrous oxide from arid and semi-arid land, in: Dryland Ecohydrology, edited by D'Odorico, P. and Porporat, A., 233-255, Springer, Dordrecht, The Netherlands, 2006.

Müller, J.-F. and Stavrakou, T.: Inversion of $\mathrm{CO}$ and $\mathrm{NO}_{\mathrm{x}}$ emissions using the adjoint of the IMAGES model, Atmos. Chem. Phys., 5, 1157-1186, doi:10.5194/acp-5-1157-2005, 2005.

Olson, J.: World ecosystems (WE1.4): Digital raster data on a 10 min geographic 1080x2160 grid square, in: Global ecosystems database, Version 1.0: DISC A, edited by Kineman, J. and Ochrenschall, M., NOAA National Geophysical Data Center, Boulder, Colorado, USA, 1992.

Papke, H. and Papen, H.: Influence of acid rain and liming on fluxes of $\mathrm{NO}$ and $\mathrm{NO}_{2}$ from forest soil, Plant Soil, 199, 131-139, 1998.

Pongratz, J., Reick, C., Raddatz, T., and Claussen, M.: A reconstruction of global agricultural areas and land cover for the last millennium, Global Biogeochem. Cy., 22, GB3018, doi:10.1029/2007GB003153, 2008.

Richter, J. and Roelcke, M.: The N-cycle as determined by intensive agriculture - examples from central Europe and China, Nutr. Cycl. Agroecosys., 57, 33-46, 2000.

Roeckner, E., Bäuml, G., Bonaventura, L., Brokopf, R., Esch, M., Giorgetta, M., Hagemann, S., Kirchner, I., Kornblueh, L., Manzini, E., Rhodin, A., Schlese, U., Schulzweida, U., and Tompkins, A.: The atmospheric general circulation model ECHAM5. PART I: Model description, Tech. Rep. MPIReport 349, Max Planck Institute for Meteorology, available at: http://www.mpimet.mpg.de/en/wissenschaft/publikationen/ mpi-report-1987-2004.html, 2003.

Roeckner, E., Brokopf, R., Esch, M., Giorgetta, M., Hagemann, S., Kornblueh, L., Manzini, E., Schlese, U., and Schulzweida, U.: Sensitivity of simulated climate to horizontal and vertical resolution in the ECHAM5 atmosphere model, J. Climate, 19, 3771-3791, 2006.

Rondón, A., Johansson, C., and Sanhueza, E.: Emission of nitric oxide from soils and termite nests in a trachypogon savanna of the Orinoco Basin, J. Atmos. Chem., 17, 293-306, 1993.

Sanhueza, E.: Impact of human activity on NOsoil fluxes, Nutr. Cycl. Agroecosys., 48, 61-68, 1997.

Scheffer, F. and Schachtschabel, P.: Lehrbuch der Bodenkunde, Spektrum Akademischer Verlag, Heidelberg, 15 edn., 2002.

Stavrakou, T., Müller, J.-F., Boersma, K. F., De Smedt, I., and van der A, R. J.: Assessing the distribution and growth rates of $\mathrm{NO}_{\mathrm{x}}$ emission sources by inverting a 10-year record of $\mathrm{NO}_{2}$ satellite columns, Geophys. Res. Lett., 35, L10801, doi:10.1029/2008GL033521, 2008.

Stehfest, E. and Bouwman, L.: $\mathrm{N}_{2} \mathrm{O}$ and $\mathrm{NO}$ emission from agricultural fields and soils under natural vegetation: summarizing available measurement data and modeling of global annual emissions, Nutr. Cycl. Agroecosys., 24, 207-228, 2006.

Steinkamp, J., Ganzeveld, L. N., Wilcke, W., and Lawrence, M. G.: Influence of modelled soil biogenic NO emissions on related trace gases and the atmospheric oxidizing efficiency, Atmos. Chem. Phys., 9, 2663-2677, doi:10.5194/acp-9-2663-2009, 2009.

Sterling, S. and Ducharne, A.: Comprehensive data set of global land cover change for land surface model applications, Global Biogeochem. Cy., 22, GB3017, doi:10.1029/2007GB002959, 2008.

Tost, H., Jöckel, P., and Lelieveld, J.: Influence of different convection parameterisations in a GCM, Atmos. Chem. Phys., 6, 54755493, doi:10.5194/acp-6-5475-2006, 2006.

Uppala, S. M., Kallberg, P. W., Simmons, A. J., Andrae, U., Bechtold, V. D., Fiorino, M., Gibson, J. K., Haseler, J., Hernandez, A., Kelly, G. A., Li, X., Onogi, K., Saarinen, S., Sokka, N., Allan, R. P., Andersson, E., Arpe, K., Balmaseda, M. A., Beljaars, A. C. M., Van De Berg, L., Bidlot, J., Bormann, N., Caires, S., Chevallier, F., Dethof, A., Dragosavac, M., Fisher, M., Fuentes, M., Hagemann, S., Holm, E., Hoskins, B. J., Isaksen, L., Janssen, P. A. E. M., Jenne, R., McNally, A. P., Mahfouf, J. F., Morcrette, J. J., Rayner, N. A., Saunders, R. W., Simon, P., Sterl, A., Trenberth, K. E., Untch, A., Vasiljevic, D., Viterbo, P., and Woollen, J.: The ERA-40 re-analysis, Q. J. Roy. Meteor. Soc., 131, 29613012, doi:10.1256/qj.04.176, 2005.

van $\operatorname{der}$ A, R. J., Eskes, H. J., Boersma, K. F., van Noije, T. P. C., Van Roozendael, M., De Smedt, I., Peters, D. H. M. U., and Meijer, E. W.: Trends, seasonal variability and dominant $\mathrm{NO}_{\mathrm{x}}$ sources derived from a ten year record of $\mathrm{NO}_{2}$ measured from space, J. Geophys. Res., 113, D04302, doi:10.1029/2007JD009021, 2008.

Vogt, K. A., Grier, C. C., and Vogt, D. J.: Production, turnover, and nutrient dynamics of above- and belowground detritus of world forests, Adv. Ecol. Res., 15, 303-377, 1986.

Wang, Y., McElroy, M. B., Martin, R. V., Streets, D. G., Zhang, Q., and Fu, T.-M.: Seasonal variability of $\mathrm{NO}_{\mathrm{x}}$ emissions over east China constrained by satellite observations: Implications for combustion and microbial sources, J. Geophys. Res., 112, 
D06301, doi:10.1029/2006JD007538, 2007.

Yienger, J. J. and Levy, H.: Empirical model of global soil-biogenic $\mathrm{NO}_{\mathrm{x}}$ emissions, J. Geophys. Res., 100, 11447-11464, 1995.

Zhao, C. and Wang, Y.: Assimilated inversion of $\mathrm{NO}_{\mathrm{x}}$ emissions over east Asia using $\mathrm{OMI} \mathrm{NO}_{2}$ column measurements, Geophys. Res. Lett., 36, L06805, doi:10.1029/2008GL037123, 2009.
Zheng, X., Huang, Y., Wang, Y., and Wang, M.: Seasonal characteristics of nitric oxide emission from a typical Chinese rice-wheat rotation during the nonwaterlogged period, Global Change Biol., 9, 219-227, 2003. 